\title{
Onset of the Iberian Upwelling along the Galician coast
}

\author{
R. Torres ${ }^{a, *}$ E.D. Barton ${ }^{b}$ \\ ${ }^{a}$ Plymouth Marine Laboratory, Plymouth, U.K. \\ ${ }^{\mathrm{b}}$ Instituto de Investigaciones Marinas, Vigo, Spain
}

\begin{abstract}
Through a set of observations including satellite, cruise and mooring data during May-July 1997 the transition between the downwelling and upwelling regimes off Galicia has been characterized. The poleward flow,typical of downwelling, was associated with a series of mesoscale eddies and interacted with coastal freshwater inputs. The poleward flow along the continental slope was separated into an offshore branch and a nearshore branch by a well defined equatorward flow and both associated with a prominent salinity maximum. With the onset of upwelling-favorable winds, equatorward flow was established over the entire shelf. At the same time, a buoyant, warm surface layer spread out over the shelf from the Rías as water previously forced in by southerly winds was flushed out by the upwelling winds. The completed transition to summertime coastal upwelling took place after the cruise but was evident in satellite images. A conceptual model is used to demonstrate that the coastal orientation with respect to the upwelling winds enhances offshore flow outside the Rías and displaces the poleward flow offshore after several days of upwelling.
\end{abstract}

Key words: Iberia, Spring transition, upwelling, circulation 


\section{$1 \quad 1$ Introduction}

2 The Iberian upwelling is driven by the trade winds between May and October

3 (Wooster et al., 1976). Cyclonic wind stress curl enhances this seasonal

4 upwelling offshore of the coast (Bakun and Nelson, 1991), while orographic

5 influences can be important near capes and the large inlets of the Rías Baixas

6 (McClain et al., 1986). The wind forcing is highly variable with a time scale of

7 10-15 days (Nogueira et al., 1997), leading to repeated spin up and relaxation

8 of upwelling. In fact, the seasonal wind signal is often masked, with upwelling

9 and downwelling winds distributed year-around (Torres et al., 2003). The

10 authors found that cycles of upwelling-winds/relaxation in Galicia show large

11 variability in wind speed, direction and persistence with typical patterns of

12 upwelling favourable wind fields forcing different responses in the system,

13 generating upwelling either north of Cape Finisterre or along the Atlantic west

\footnotetext{
* Plymouth Marine Laboratory, Plymouth, U.K.
} 
data for the period 1987-1992 (Nogueira et al., 1997). From November to March, thermal inversion takes place, the water column becomes briefly homogeneous in early April but quickly stratifies and remains so until October, when thermal inversion develops once more. Similar trends can be expected on the shelf, considering the strong linkage between the Rías and the shelf (Álvarez-Salgado et al., 2000).

The spring transition is defined as the period during which the winter regime of predominant downwelling and poleward flow over the continental shelf and slope is replaced by a regime of sustained coastal upwelling. There are few examples from upwelling regions worldwide. For example, the spring transition is fast in the California system (Huyer, 1983) with a time scale of few days, but is not well known elsewhere. Off Iberia the seasonal cycle between regimes is associated with changes in the meridional density gradient, for example inferred from sea surface temperature (SST) (Peliz et al., 2005). This latitudinal gradient is the main driving mechanism for the poleward slope current, the Iberian Poleward Current (IPC) which displays maximum flow in winter (average speed of $15-20 \mathrm{~cm} \mathrm{~s}^{-1}$ (Haynes and Barton, 1990; Torres and Barton, 2006)), and reverses to southward flow during the summer (Haynes and Barton, 1990; Huthnance et al., 2002; Torres and Barton, 2006). In the absence of any steady sea level gradient or stratification, the response of the Galician system to upwelling favorable wind is stronger than during well established upwelling (Castro et al., 2000). During the transition, there could be short periods during which poleward flow offshore and upwelling nearshore coexist. Indeed, coexistence of the IPC and coastal upwelling has been previously reported (Castro et al., 1997; Peliz et al., 2002). A further poleward flow structure associated to a low salinity plume of coastal origin 
off Portugal (Western Iberian Buoyant Plume or WIBP) has also been linked to transitional periods in the Iberian system (Sordo et al., 2001; Peliz et al., 2002) and has been described as a precursor to the occurrence of harmful algal blooms in the Ría De Vigo (Sordo et al., 2001).

The Rías Baixas, major coastal inlets formed of sunken river valleys, have recently been recognized to form an intrinsic component of the "shelf system" (Doval et al., 1998) driven by large scale and local winds, especially during summer when freshwater input is at its minimum. The downwelling winds and the presence of the poleward flow over the shelf prevents the "outwelling" or water discharge from the Rías Baixas, detaining it over the inner shelf (Castro et al., 1997) and even forcing shelf water into the Rías Baixas at times (e.g. Prego et al., 2001; Sordo et al., 2001). During upwelling winds, upwelling takes place inside the Rías (Álvarez-Salgado et al., 2000) enhancing flushing of the semi-enclosed system.

The current work aims at explaining the mechanisms involved in the spring transition, in particular, the changes in the shelf circulation arising from the interaction of coastal upwelling and slope poleward flow. In the next sections data from a cruise in June 1997 coincident with the spring transition are analyzed. The data are analyzed in a broader temporal context established by SST images before and after the cruise. The sampling strategy is presented first, followed by the data description and analysis techniques. Horizontal and vertical distribution of properties and velocity vectors are described next, and particular attention is placed on the interaction of the outflow from the Rías and the offshore circulation. We finish with the discussion and main conclusions. 
77 The RRS Charles Darwin Cruise 105 took place off the Galician coast from

29 May to 20 June 1997 as part of the OMEX II-II project. Leg A took place from 29 May to 8 June, and leg B from 10 to 20 June.

Leg A was dedicated to geophysical survey of the topography of the continental slope and so only underway Temperature and Salinity were recorded for that period. During leg B, CTD casts were made to the full water column depth over a grid of stations roughly separated 10 by $18 \mathrm{~km}$. The separation, smaller than the local internal Rossby radius of $20-30 \mathrm{~km}$, provided enough detail to resolve mesoscale structures. However, the 10 days taken to complete the survey compromised its synopticity. Downwelling favorable wind conditions prevailed for the first four days of Leg B with northerly winds increasing thereafter until the end of the cruise on 20 June. The three northernmost grid lines (Transects 1,2 and 3, Fig 1) were begun on 11 June during downwelling wind conditions, while the remainder of the grid was completed northwards from the southernmost deep station in the order 4-9 under upwelling conditions.

\footnotetext{
A total of 82 CTD stations were sampled with a Neil Brown Systems Mk IIIB CTD. A Chelsea Instruments Aquatracka configured as a fluorometer was also attached to the system. Continuous underway measurements of temperature and salinity from a Falmouth Scientific Instruments Thermosalinometer were recorded every minute during both legs of the cruise from a nominal depth of $5 \mathrm{~m}$. In leg B, surface chlorophyll data were also measured by a Chelsea Instruments Aquatracka fluorometer. Position data from GPS, primarily an Ashtech 3-D GPS system, were recorded every second.
} 
An RDI Acoustic Doppler Current Profiler (ADCP) was mounted roughly amidships at $5 \mathrm{~m}$ below the water. The $150 \mathrm{kHz}$ instrument was set up with a pulse length of $4 \mathrm{~m}$, a band width of $4 \mathrm{~m}$, a blanking interval of $4 \mathrm{~m}$, and an ensemble averaging of $5 \mathrm{~min}$. The error velocity threshold for raw pings during acquisition was $1 \mathrm{~m} \mathrm{~s}^{-1}$ and bins with less than $25 \%$ of percentage good (PG) were automatically flagged. No correction for pitch and roll were made; errors associated with these are likely to be small (Kosro, 1985). Processing of the ADCP data (10-20 June) with the Common Oceanographic Data Access System (CODAS) (Firing et al., 1995) is detailed in (Torres and Barton, 1999) and a thorough description of the steps involved can be found in [http://currents.soest.hawaii.edu/docs/adcp_doc/index.html]. Relatively poor data quality, probably related to the physical installation in RRS Darwin, was partly compensated by averaging over larger vertical (10m or larger) and time (10min) intervals than usual.

Calculation of the amplitude $(\beta)$ and phase $(\alpha)$ correction factor were carried out using the water track method (Pollard and Read, 1989) resulting in 1.02 $( \pm 0.01)$ and $-7.2( \pm 0.5)$ degrees respectively. At worst (at highest ship speed of $\sim 5 \mathrm{~m} \mathrm{~s}^{-1}$ ), the $\beta$ and $\alpha$ uncertainties imply an unknown bias of $5 \mathrm{~cm} \mathrm{~s}^{-1}$ in velocity measurements.

Coastal winds were recorded at three locations along the Galician coast at Vilanova, Finisterre and Corrubedo (Fig 1) for the months of June and July. The wind flows predominantly along the direction of the coast and spatial differences are expected due to the complex coastline of the region. Although these might not be representative of the more complex large scale winds (e.g. 


\subsection{Streamfunction Estimates of non-divergent flow}

In order to minimize the described limitations of the ADCP data set due to instrumental errors, and the aliasing effects of tidal and inertial signals, the streamfunction for the ADCP velocities is derived (Eq. 1).

$$
\nabla^{2} \psi=\frac{\partial v}{\partial x}-\frac{\partial u}{\partial y}
$$

following Barth et al. (2000) and Pierce et al. (2000). Gridded fields of $\mathrm{U}$ and $\mathrm{V}$ components at selected depths were built using a four-pass Barnes objective analysis (OA) scheme (Barnes, 1994; Koch et al., 1983). The gridded field is estimated by iteratively applying a Gaussian-weighted average converging towards the observed points. To account for the larger uncertainties in the underway data, ship velocity weights were used together with the distance-based weighting. Although related to statistical optimal interpolation, this method does not require prior specification of a covariance model for the observed field. The Barnes radii corresponded to $7 \mathrm{~km}$ and $11 \mathrm{~km}$ in the $\mathrm{X}$ and $\mathrm{Y}$ directions so that scales larger than these were not smoothed. The streamfunction was then calculated for the gridded levels using the version III method of Hawkins and Rosenthal (1965), also described by Carter and Robinson (1987), which represents an alternative way of estimating the streamfunction values at the boundaries. The method derives from the Helmholtz theorem (Eq. 2) which allows the separation of a velocity field into a non-divergent part and an irrotational component. $\bar{V}$ is the horizontal 
velocity, $K$ is the unit vertical vector, $\psi$ is the horizontal streamfunction (the non-divergent part) and $\eta$ is the horizontal velocity potential (the irrotational part).

$$
\bar{V}=K \times \nabla \psi+\nabla \eta
$$

Taking the scalar product of Eq. 2 with n, the unit outward normal vector, we get,

$$
\frac{\partial \psi}{\partial s}=-\bar{V}_{n}+\frac{\partial \eta}{\partial n},
$$

where $s$ is the distance along the boundary in a counterclockwise direction, and $\bar{V}_{n}$ is the velocity normal to the boundary. By integrating Eq. 3 around the boundary, we get $\psi$ values at the boundary that will be used in the streamfunction calculations (Eq. 1), rather than using the observed velocity field, which need not be non-divergent given the measurement noise. Because boundary values of $\eta$ calculated from the observed velocity field as in Eq. 4 are subject to noise in the measurements, a value of $\eta=0$ was imposed at the boundary. In this way, the total kinetic energy of the $\psi$ field is maximized while minimizing the amount of energy in the $\eta$ field (Carter and Robinson, 1987).

$$
\nabla^{2} \eta=\nabla \cdot \bar{V} .
$$

The Poisson equations Eq. 1-4 were solved by the capacitance matrix method of Cummins and Vallis (1994), which handles Dirichlet boundary conditions in an irregular domain. Non-divergent vectors are derived from the gridded streamfunction and then interpolated back to their original locations using improved Akima bivariate interpolation (Akima, 1996). The Barnes OA and 
the streamfunction derivation together amount to a method of systematically applying conservation of mass throughout a region (Pierce et al., 2000). The derivatives were calculated with central differences in the interior points while forward difference was used at the boundaries. Trapezoidal numerical integration was used in all integral calculations.

[Fig. 2 about here.]

An example of the vectorized ADCP data and non-divergent current vectors centered at $51 \mathrm{~m}$ is shown in Fig. 2. ADCP current vectors (Fig 2a) were averaged in cells of $0.05 \times 0.05^{\circ}$. The non-divergent field clearly reproduces the large scale features seen in the raw field. The offshore poleward flow, coastal southward jet and the two eddies are all well defined in the non-divergent field. It is important to bear in mind that strong wind changes took place during the cruise, mostly affecting the nearshore region, and the non-divergent field is a smoothed version of the raw field. Unless otherwise stated, transport figures refered to in the text correspond to a layer thickness identical to the vertical averaging of the ADCP raw data, i.e. $12 \mathrm{~m}$.

\section{Results}

\subsection{SST and wind conditions prior, during and after the cruise}

The CD105 cruise took place during the Galician transition from the poleward flow dominated winter regime to the upwelling summer regime. The weekly SST composite images in Fig 3 correspond to 1-7 June, coincident with leg A, and 29-05 July, nine days after the completion of LEG B. In Fig 3a the 
characteristic warm signal of the winter poleward flow is seen extending north along the outer slope and shelf, but it is separated into two by a narrow colder zone along the $1000 \mathrm{~m}$ isobath. Coastal warm waters extended offshore to the $200 \mathrm{~m}$ isobath and to the north of Finisterre, with temperature decreasing northwards. The separation of the two warm tongues occurs near $41^{\circ} \mathrm{N}$. Eddy like structures with scales of $30 \mathrm{~km}$ are evident in the offshore warm tongue (E1-E3 ) but not in subsequent images possibly because of the storm of 6-8 June (e.g. Fig 4). While E1 was observed in the hydrography and velocity fields E3 was not discernible in the data possibly due to its advection offshore of the sampling area or because it was an artifact of the composite technique used in the satellite data generation. In the following two weeks, the offshore branch of the warm tongue weakened and receded southwards and by the third week it did not extend beyond $42.5^{\circ} \mathrm{N}$ (Fig $3 \mathrm{~b}$ ). The coastal tongue disappeared and was replaced by a coastal band of upwelled water extending offshore to the $200 \mathrm{~m}$ isobath (Fig 3b).

[Fig. 3 about here.]

Wind conditions during leg A (Fig 4) were downwelling-favorable until 13 June. Peak winds of $15 \mathrm{~m} \mathrm{~s}^{-1}$ and $12 \mathrm{~m} \mathrm{~s}^{-1}$ occurred at Vilanova and Corrubedo, respectively, on 6-8 June when a storm hit the region. From 13 July on, winds were increasingly equatorward up to speeds $>10 \mathrm{~m} \mathrm{~s}^{-1}$. Hence, four days after the start of leg $\mathrm{B}$, the regime changed from a strongly downwelling scenario to an increasingly upwelling favourable one that persisted through July.

[Fig. 4 about here.] 
3.1.1 Assessing the variability during CD105

[Fig. 5 about here.]

Changes due to the wind shift during the cruise are evident nearshore when comparing underway data (temperature, salinity and ADCP vector currents) from 10 June (before the wind shift) and 20 June (after it). Two short sections when the ship was leaving the port of Vigo following a similar path at roughly the same velocity $\left(4.5 \mathrm{~m} \mathrm{~s}^{-1}\right)$ are compared in Fig 5 . Errors induced by the uncertainty in the ADCP calibration can be assumed to be comparable during the two lines.

After the change to upwelling conditions, surface temperature near the mouth of the Rías de Pontevedra and Arousa generally increased by $1^{\circ} \mathrm{C}$ (Fig 5a), the zonal temperature gradient disappeared and west of $9^{\circ} \mathrm{W}$ salinity fell by 0.4 psu because of enhanced outwelling from the Rías. Outwelling refers to the offshore flux of Ría waters by Ekman transport (Álvarez-Salgado et al., 2000). Warm water pooled in the Rías during downwelling conditions are flushed in the initial response to upwelling, hence the temperature increase. Outflow from more southern origin like the Duoro River would also produce a thin surface layer that would be subject to strong heating and locally increased temperatures. These changes are larger close to shore, as expected. The narrow tongue of lower salinity/higher temperature measured east of $9^{\circ} \mathrm{W}$ on $20 \mathrm{June}$ probably originated in the Ría de Arousa.

At the time of the first line, the flow in the upper 50m (Fig 5b) was $\sim 20 \mathrm{~cm} \mathrm{~s}^{-1}$ northward, roughly paralleling the coast . At the end of cruise, the flow had reversed with the wind shift, with velocities up to $\sim 35 \mathrm{~cm} \mathrm{~s}^{-1}$. Both flows had a narrow jet-like geometry with similar zonal scales. The low 


\subsection{Horizontal Fields}

\subsubsection{Surface layer $(5 \mathrm{~m})$ fields}

The near-surface salinity and temperature distribution $(5 \mathrm{~m})$ recorded from the thermosalinograph for legs A and B are shown in Fig 6. Although it is difficult to consider the Leg B fields as truly synoptic in the light of these wind changes, they will be discussed initially as if they were snapshots.

During the downwelling conditions of Leg A (Fig 6a) the salinity range was small (36.08-35.70psu) with the exception of an isolated low salinity patch ("L" in the graph) and the SE corner of the survey, where it fell to about $35.5 \mathrm{psu}$. A tongue of slightly higher salinity (P) lay along $9.9^{\circ} \mathrm{W}$, coincident with a warm feature in the simultaneous surface temperature survey (Fig 6c) and SST composite image of leg A (Fig 3). The low salinity regions possibly originated in the Rías Baixas, between $42.2^{\circ}$ and $42.5^{\circ} \mathrm{N}$, although they more likely form part of a more general inshore, fresher water zone with its origin in estuarine outflow further south. Leg A sampling did not extend close enough to shore to ascertain which was the case. In the south of the area, part of the inshore warm tongue was evident where it separated from the offshore branch.

In leg B (Fig 6b and c), the sampling extended further shoreward to include nearshore stations within the $<100 m$ depth contour and the salinity range widened to include lower values (36-30.5 psu). This sampling period was 
characterized by upwelling favorable winds after the time of the first three northern sections. The low salinity region L was now clearly an offshore extension of a coastal band of low salinity water, presumably of estuarine origin, that extended from the southern limit of the sampling area to the Rías Baixas. Further north, it was retained closer to the coast. The northward increase in width of the low salinity band from the south of the area to the Rías Baixas is compatible with developing upwelling and associated surface Ekman transport. The low salinity band was separated by a strong salinity front from the high salinity tongue offshore ( $\mathrm{P}$ in the graph) with $\triangle S>0.4$ psu. The high salinity tongue $\mathrm{P}$ broadened in the south of the area during leg $\mathrm{B}$ and meandered north of $42.25^{\circ} \mathrm{N}$. The structure E2, previously identified in the SST images, was evident as a localized salinity maximum $\mathrm{S}>35.85$ psu. An initially surprising feature of the temperature map (Fig 6d) is the nearshore band of higher temperatures in the southern part of the area. This is in marked contrast to the situation one week after the cruise (Fig 3) when cold nearshore temperatures indicated the presence of upwelling. The extended warm nearshore plume corresponds closely to the low salinity band and represents the offshore spread by Ekman transport of water previously trapped against the coast.

[Fig. 6 about here.]

[Fig. 7 about here.]

The un-calibrated fluorescence data at $5 \mathrm{~m}$ depth from leg B (Fig 7a) resembles the salinity field, with high fluorescence values related to low salinity. The higher salinity tongue $\mathrm{P}$ had associated low fluorescence values $(<0.5 \mathrm{~V})$. Values were higher close to the mouth of the Rías and the river Miño, where 
the highest values were measured $(>1 \mathrm{~V})$, but decreased rapidly offshore on scales of $<20 \mathrm{~km}$. The low salinity tongue L can be seen in Fig 7a as a region of fluorescence in the range $0.55-65 \mathrm{~V}$ extending offshore near $42.4^{\circ} \mathrm{N}$.

The mixed layer distribution (Fig $7 \mathrm{~b}$ ) was calculated using as criterion the density difference with the surface, where $\Delta \sigma_{t}=0.1 \mathrm{~kg} \mathrm{~m}^{3}$ (Brainerd and Gregg, 1995). Maximum depths ( $>40 \mathrm{~m})$ were measured in the northern limit of the survey area while minimum values were encountered nearshore south of $42.25^{\circ} \mathrm{N}$. The latter corresponds to the region influenced by the freshwater runoff from the rivers. The low salinity plume L had typical mixed layer depths of $20 \mathrm{~m}$. The center of the eddy E2 was characterized by mixed layer depths as much as $20 \mathrm{~m}$ deeper than surrounding waters.

[Fig. 8 about here.]

\subsubsection{Near-Surface (15m) fields}

Horizontal fields at the level of the shallowest reliable ADCP bin $(12 \mathrm{~m}$ bin centered at $15 \mathrm{~m}$ depth) are shown in Fig 8 . The salinity and fluorescence contours (8a-b) show some significant differences when compared to the $5 \mathrm{~m}$ fields. The lower salinity coastal band south of $42.15^{\circ} \mathrm{N}$ had almost disappeared although a narrow band of high fluorescence was still visible $15 \mathrm{~km}$ off the coast. The P showed an offshore branch, and a coastal branch, only slightly evident at $5 \mathrm{~m}$ along the slope as far as $42.15^{\circ} \mathrm{N}$. The low salinity region $\mathrm{L}$ extended down to $15 \mathrm{~m}$ but with minimum values $(<35.5)$ closer to shore than at the surface. The eddy E2 was just visible and relatively high salinity was reached nearshore north of $42.7^{\circ} \mathrm{N}$. The fluorescence field shows a similar pattern to the $5 \mathrm{~m}$ level, however higher values extend further offshore 
The non-divergent current field and overlaid contours of streamfunction transport for the $12 \mathrm{~m}$ thick layer centred at $15 \mathrm{~m}$ are shown in Fig 8c. Nearshore, a narrow southward flow, strongest and widest around $42.25^{\circ} \mathrm{N}$, extended from $42.5^{\circ} \mathrm{N}$ to the southern edge of the area, sampled under upwelling-favourable winds. The poleward flow was separated into two cores of stronger flow. The offshore core entered the area in the southwest with a transport of $0.04 \mathrm{~Sv}$ to exit again between 42.0 and $42.5^{\circ} \mathrm{N}$. The other entered across the southernmost line with $0.02 \mathrm{~Sv}$, then became concentrated over the slope. At $42.2 \mathrm{~N}$ this branch turned offshore on encountering the broadest part of the nearshore southward flow, and looped anticyclonically further north. North of $42.5^{\circ}$, the three lines sampled under downwelling conditions all showed poleward flow offshore, equatorward flow over the inner slope and poleward flow close to the coast. A small, intense cyclonic eddy embedded within this pattern corresponded to the temperature and salinity feature E2. Recalling the asynoptic nature of the sampling and the wind reversal, it seems likely that the change from poleward flow nearshore on the three northernmost lines to southward on the rest reflects the spin up of a southward coastal jet in response to upwelling favourable winds. The strongest equatorward flow was recorded on the last section to be sampled.

\subsubsection{Sub-surface fields $(50 \mathrm{~m})$}

The salinity field below the mixed layer ( at 50m, Fig 9a) shows the offshore salty tongue along the western limit of the grid more clearly. Salinity was 
higher $(36 p s u)$ in the offshore branch than in the separate coastal branch (35.95-35.90psu). The high salinity eddy E2 appears shifted to the west. Little sign of the coastal freshwater plume seen at shallower levels is apparent at $50 \mathrm{~m}$. The fluorescence field (not shown) also lacks the high coastal values seen at shallower levels.

The non-divergent field (Fig 9c) shows the offshore branch of poleward flow was still strong $\left(\sim 20-25 \mathrm{~cm} \mathrm{~s}^{-1}\right)$ at the western limit of the sampled region with a transport of at least $0.03 \mathrm{~Sv}$. The nearshore poleward flow in the north and the anticyclonic eddy E2 were as strong as at $15 \mathrm{~m}$ depth. However, some of the offshore waters returned to the shelf north of the eddy, apparently joining the weak coastal southward flow, which could be seen in all the lines south of $42^{\circ} \mathrm{N}$ (though we recall the discontinuity in sampling between lines 3 and 9).

(1) Fig 9b) indicates insignificant aliasing by internal waves and tides. Higher temperatures were associated with the higher salinity offshore poleward flow as expected but the apparent center of the eddy E2 was positioned east of the high salinity anomaly, in better agreement with the non-divergent current vectors.

Similar structures are present at deeper levels (Fig. 10a-b). The offshore salty and warm poleward flow was present down to $200 \mathrm{~m}$, the salinity contrast with surrounding waters decreasing with depth. The more nearshore poleward flow was completely separated from the offshore branch at $100 \mathrm{~m}$ by a low 
salinity-low temperature band running parallel to the coast. Remnants of the coastal branch (warm and salty pools) were found north and south of the Rías Baixas at 100m but disappeared at deeper levels. The eddy E2 was present down to $250 \mathrm{~m}$ with highest associated anomalies $0.1 \mathrm{psu}\left(0.8^{\circ}\right)$ salinity (temperature) at $150 \mathrm{~m}$ suggesting it is a deep seated feature, though smaller than a typical SWODDY (Pingree and LeCann, 1992).

[Fig. 10 about here.]

The non-divergent current field at $100 \mathrm{~m}$ was similar but less energetic than at shallower depths (Fig 10c). The offshore poleward flow, the northern coastal poleward current and the anticyclonic eddy were all present down to $150 \mathrm{~m}$. The offshore flow off the Rías Baixas at $42.25^{\circ} \mathrm{N}$ weakened with depth and disappeared below $150 \mathrm{~m}$. The meridional low salinity/temperature band clearly visible at $100 \mathrm{~m}$ can be traced as a southward flowing jet down to the maximum penetration of the ADCP $(200 \mathrm{~m})$, at which level a weak poleward flow was still present offshore.

\subsection{Vertical Fields}

\subsubsection{Salinity structure}

The top 300m of the salinity structure is shown in Fig 11 for transects (a) 1, (b) 3, (c) 9, (d) 7, (e) 5 and (f) 4 (locations in Fig 1). Two cores of higher salinity (>35.9psu) can be seen in the range $50-150 \mathrm{~m}$ over the shelf and at $\sim 70 \mathrm{~km}$ offshore. These are associated with the poleward flows seen earlier. The offshore core is consistently shallower and has higher salinity than the shelf core. The cores are almost merged into a single feature in the southernmost 
section, transect 1 (Fig 11f), and are increasingly separated towards the north.

Although the maximum core salinities are located at 50 to $100 \mathrm{~m}$ depth, locally high salinities extend down to $300 \mathrm{~m}$.

[Fig. 11 about here.]

The two salinity cores separate, decrease in maximum salinity, and become deeper with increasing latitude. The cores are most widely separated in section 7 (Fig 11d). From this section northwards, the isohalines below $150 \mathrm{~m}$ slope downwards towards the coast, reflecting the dominance of poleward flow before and at the start of the upwelling favorable wind. The thin $(<20 \mathrm{~m})$ layer of fresher Ría waters extended most offshore in the central sections and was most strongly concentrated against the coast in the early northern sections. This again agrees with the idea of downwelling influence in the first sections sampled and increasing effect of upwelling and offshore Ekman flow in succeeding ones. Transect 3 (Fig 11b) showed the broadest and deepest offshore salinity core (50-150m), which coincided in position with the anticyclonic eddy.

[Fig. 12 about here.]

\subsubsection{Alongshore flow regime}

In general a largely barotropic poleward flow was associated with the offshore half of the high salinity cores. Between the two salinity cores, equatorward flow was measured in a relatively narrow band at all depths. Poleward flow was measured over the shelf on all transects but 9 .

The relation between poleward flow and the salinity cores was not simple.

Two factors of probable relevance are the more widely spaced sampling of 
salinity compared to velocity and the rapidly changing situation resulting from the onset of upwelling favourable winds. Wherever equatorward flow was present the salinity maximum was weakened or absent, as in Figs 11 and $12 \mathrm{a}, \mathrm{b}$ and $\mathrm{d}$. The offshore branch of the poleward current had typical values $10-15 \mathrm{~cm} \mathrm{~s}^{-1}$, was strongest in section 9 and weakest in section 4 . The nearshore, shelf poleward flow was most defined in the early northern sections, especially 1 (Fig 12a), where the highest poleward velocities of all were measured against the coast. The band of equatorward flow was also relatively barotropic with velocities up to $20 \mathrm{~cm} \mathrm{~s}^{-1}$. In the later, more southern sections, weak equatorward flow appeared over the shelf, and in section 9 (Figs 12c) an intensified coastal jet was evident. So again the evidence suggests a shelf response to the change to upwelling winds after the first three sections in which initial poleward flow over shelf and inner slope was replaced by an increasingly equatorward tendency.

[Fig. 13 about here.]

\subsubsection{Density structure}

The density distribution was largely determined by the temperature structure and showed a pycnocline centered at 50m overall, but the influence of the low salinity near surface along the coast was also evident. Isopycnals tended to rise locally above, and deepen below, the sub-surface salinity maxima seen in Fig 11. The pycnocline was thicker in the south $(50 \mathrm{~m})$ than in the north (30m). A general downward slope of the isopycnals towards shore over the shelf was most pronounced in the northern sections (Figs 13a-b,) suggestive of sinking during downwelling favourable winds. This was consistent with a 
bottom Ekman layer in the stronger poleward flow found close to shore in these sections, and the near-bottom ADCP cross-shelf velocity component did register albeit weak (less than $5 \mathrm{~cm} \mathrm{~s}^{-1}$ ) offshore flow (not shown).

Despite the change to upwelling favorable winds before the remaining sections only transect 9 (Fig 13c), showed uplifted isopycnals as deep as $60 \mathrm{~m}$ over the shelf. The upwelling response was probably retarded by the strong stratification related to the fresher water surface plume and the requirement for the upwelling circulation to flush the Rías. The observation that the shallow surface low density layer extended furthest offshore in section 9 is compatible with offshore advection in the surface Ekman layer.

The northward velocity component field showed qualitatively good agreement with the density structure. Some of the discrepancies between the velocity and density field on short scales could come from the different resolution of the samplings. The downward sloping of the isopycnals over the shelf edge is compatible with geostrophic northward flow against the sloping bottom (e.g Fig 13-12b). When this is not the case, forces other than Coriolis and pressure are needed for dynamical balance, which is not surprising as we have seen that the sampling took place during a transitional period.

\section{Discussion}

The transition between the downwelling winter regime and the upwelling summer regime typically takes place in June (Nykjaer and Vancamp, 1994), two months after the onset of the spring warming (Nogueira et al., 1997). The

RRS Charles Darwin CD105 cruise took place during the transition from the 
winter downwelling to the summer upwelling season, from 10 to 20 June.

457

\subsection{General circulation}

During Leg A, surface salinity indicated the presence of a contorted poleward current, the Iberian poleward current (IPC) following the slope. The weekly SST average from satellite images showed a similar pattern, with higher temperatures associated with the higher salinity tongue. Along the warm tongue, several warm patches suggested anticyclonic eddies with a spatial scale of $\sim 30-40 \mathrm{~km}$.

Nearshore, a second warm surface tongue extended from the south of the sampling area to $43.5^{\circ} \mathrm{N}$, but not into the Cantabrian sea. This tongue was associated with low surface salinity originating in coastal runoff from Galicia and further south. Outflow of the Río Miño, typically 5-10 times greater than that of the rivers supplying the Rías, at times is advected northwards to enter the southermost Rías (Alvarez et al., 2006). A low salinity plume of coastal origin off Portugal was described by Peliz et al. (2002), who named it the Western Iberian Buoyant Plume (WIBP). Their observations took place in early September 1998, during the spin down of upwelling. As reported here, poleward flow was found over both slope and nearshore. Similar SST structure in September of four different years was interpreted by (Sordo et al., 2001) as evidence of nearshore poleward flow as a precursor to the occurrence of harmful algal blooms in the Ría De Vigo.

During Leg B, some 10 days later and following the change to upwelling-favourable winds, the in situ observations showed a chronological sequence of replacement 
of the nearshore surface poleward flow by a southward jet and the development of upwelling. The early sections in the north exhibited the strongest nearshore poleward flow and tight coastal trapping of the low salinity buoyant plume, while the final sections in the centre of the area showed the most well-defined equatorward jet and offshore stretching of the WIBP by surface Ekman transport. The onset of upwelling was also evidenced by the change from shoreward down-warping of shelf isopycnals to upwarping above $60 \mathrm{~m}$ in the later sections. Sampling nearshore demonstrated that the early stage of upwelling flushed warmer, low salinity surface water from the Rías and WIBP, but shortly after the end of the cruise SST images showed the nearshore warm waters had been replaced by a band of colder upwelled water.

High salinity values are the distinctive mark of the IPC. Previous studies of the IPC in the west coast of Iberia $\left(40^{\circ} \mathrm{N}\right)$ have also found a high salinity core at 100m close to the slope (Frouin et al., 1990; Haynes and Barton, 1990; Peliz et al., 2002). On this occasion, the separation of the poleward flow into two cores with related salinity maximums is however surprising. The poleward flow over the inner slope was contiguous with that of the surface layer buoyant plume, but weakened or disappeared in the later sections as upwelling developed. Although similar structure of the poleward flow was reported by Peliz et al. (2002) for winter and by Torres and Barton (2006) for autumn, the salinity maximum was present only in the offshore nucleus of flow. Here, the offshore salinity maximum coincided with northward velocities up to $15 \mathrm{~cm} \mathrm{~s}^{-1}$ similar to the average speed of $20 \mathrm{~cm} \mathrm{~s}^{-1}$ measured by Haynes and Barton (1990). Lower northward velocities were associated with the shelf edge salinity maximum. Between the two salinity maxima, southward flow was present in all transects in association with a wedge of lower salinity and temperature 
at all depths. SST images implied it advected waters from north of Cape Finisterre and was present as early as May. This is possible because wind forcing in the area is far from uniform (Torres et al., 2003) and it is often the case that upwelling winds occur near Finisterre but not further south. Thus, cool equatorward shelf flow generated in the upwelling further north can encounter warm poleward coastally trapped flow further south and be forced away from the coast. In the present case, upwelling had not been established yet anywhere along the coast. It is probable however that the slope and coastal poleward flows originate independently, the former driven by the large scale pressure gradients and the latter by local buoyancy forcing. Equatorward flow separating two poleward flow currents has also been reported near Cape Saõ Vicente, southwest Portugal (Relvas and Barton, 2005), during the spring onset of the upwelling regime. The feature was attributed to the interaction of a coastal upwelling jet, separated from a cape further north, with a locally produced coastal poleward countercurrent in association with differences in wind forcing along the coast.

The SST signal of the anticyclonic eddy E2 related to the IPC disappeared after the 6-8 June storm but the eddy remained visible in the subsurface data. It had an estimated diameter of $\sim 30-40 \mathrm{~km}$ from both surface SST and in situ data to a depth of $150 \mathrm{~m}$, carrying $\sim 128 \mathrm{~km}^{3}$. Similar eddies associated with the IPC have been previously reported (Haynes and Barton, 1991; Martins et al., 2002). This eddy was distinct from SWODDIES, which form in the Bay of Biscay (Pingree, 1994) and have also been linked to the IPC. Their characteristic radii can be three times bigger $(50-60 \mathrm{~km})$ and they reach depths of $1500 \mathrm{~km}$. However, the present data are insufficient to hypothesize about the eddy's life span or its origin. Huthnance et al. (2002) presented eddy statistics 
for the region $40.5-45.5^{\circ} \mathrm{N}$ out to $13^{\circ} \mathrm{W}$ for years $1993-1999$. Based on their SST signal eddies had a mean diameter of $\sim 52 \pm 22$ and most were found north of Cape Finisterre-Cape Ortegal, a preferred generation area (Dubert, 1998; Paillet et al., 2002). Although eddies constitute an active shelf exchange mechanism their small number (20 per year) makes a modest contribution to the overall exchange in the region (Huthnance et al., 2002).

Coexistence of the IPC and coastal upwelling has been previously reported (Castro et al., 1997; Peliz et al., 2002). Haynes and Barton (1990) reported a resurgence of upwelling producing equatorward shelf flow while flow over the outer slope remained poleward. The IPC appeared furthest offshore off the Rías Baixas, where significant seaward flow of low salinity/ high fluorescence Rías water was measured. The offshore extension of the low salinity, warm plume provides evidence that shelf waters piled up, heated and mixed with riverine flow inside the Rías during downwelling are flushed to the shelf by the upwelling circulation. Alvarez-Salgado et al. (2000) have suggested that upwelling occurs within the interior of the Rías so that flushing is enhanced. The offshore extent of the freshwater plume is governed by the interplay between the across-shelf Ekman mass transport, vertical mixing and lateral buoyancy input forced by upwelling-favourable winds. Santos et al. (2004) have demonstrated the relevance of the WIBP in winter to retention and subsequent success of sardine eggs and larvae. With better observations of the time variation of the plume, modelling similar to that of Lentz (2004) appears promising.

The change in coast and shelf orientation off the Rías Baixas might play a significant role in the offshore flow measured there. A conceptual model similar to Rosenfeld et al. (1994) with an idealized representation of the coastline hints 
at a possible mechanism favoring offshore flow off the Rías Baixas. (Fig 14).

Two coordinate systems are defined, one with $y$ positive northward and $x$ positive eastward; and a second with $x^{\prime}$ and $y^{\prime}$ defined locally cross-shelf and alongshelf respectively.

[Fig. 14 about here.]

The depth-integrated surface Ekman layer transport, E, is to the right of the uniform wind stress, $\tau$. This offshore transport results in a drop in sea level at the coast, $\eta$. The magnitude of the Ekman transport perpendicular to the coast, $E^{x^{\prime}}$, and hence $\eta$, are functions of the coastline orientation relative to $\tau$, and are greatest where the coast is more aligned with $\tau$, i.e. along segment 2. Along the entire shelf, the cross-shelf pressure gradient drives an equatorward transport $G^{y^{\prime}}$. The alongshore variation in $\eta$ leads to convergence of the alongshore geostrophic flow, $G^{y^{\prime}}$, and a poleward-directed pressure gradient force, $\left(\frac{\partial \eta}{\partial y}\right)$ near point B. Near point A, the alongshore variation of $\eta$ creates geostrophic transport divergence and an equatorward-directed pressure gradient force. Both the cross-shelf geostrophic, $G^{x}$, and Ekman, $E^{x}$, transports are seaward near point A, contributing to the offshore displacement of the slope poleward flow. Near point B, $E^{x}$ is also seaward but $G^{x}$ is shoreward, thereby reducing the offshore tendency of the flow.

\section{Conclusions}

The cruise sampled the area at a time of transition between the downwelling and upwelling regimes. Spatial patterns observed during the cruise were aliased by the change in wind conditions but can be interpreted within the context 
of the temporal change. The picture is one of complex circulation, where poleward flow over the slope coexists with coastal upwelling and strong outflow from the Rías. The interaction generates eddies in the slope poleward flow, which could contribute to breakdown of the IPC during the start of the upwelling regime.

In conclusion:

- The first stages of this transition are characterized by large variability in circulation and property distribution both on the shelf and offshore.

- The poleward flow along the slope at $41^{\circ} \mathrm{N}$ separated into branches offshore and over the inner slope, both associated with a prominent salinity maximum.

- The poleward branches were separated by a well defined equatorward flow, apparently originating off or north of Cape Finisterre.

- The inner branch was contiguous with a coastally trapped poleward flow advecting low salinity waters of the Western Iberian Buoyant Plume.

- With the onset of upwelling winds, the coastal poleward flow weakened and disappeared as equatorward flow developed on the inner shelf.

- At the same time, a surface layer of buoyant, warmer, low salinity water spread out from the Rías as water previously forced in by southerly winds was flushed out by upwelling winds.

- A conceptual model involving the orientation of the coast with respect to the upwelling winds explains enhancement of offshore flow opposite the Rías and migration of the poleward flow offshore after several days of upwelling winds.

- The cruise captured only the onset of coastal upwelling, but the complete transition to an upwelled thermocline breaking the surface nearshore was 
${ }_{606}$ evident in subsequent satellite images.

607

608

609

Obvious questions remain:

- What was the cause of the separation of the slope poleward into two cores?

- Is this a seasonally recurring feature?

- Is the coastally trapped flow of different dynamical origin?

- How does the WIBP interact with the upwelling regime, dominant in summer and occasional in winter?

The observations succeeded in glimpsing the onset of summer upwelling off northern Iberia. However, if we are to advance the understanding of the complex Iberian upwelling ecosystem as a whole, more systematic observations linked to modelling effort are clearly needed to achieve comprehension of its underlying physical basis.

\section{Acknowledgements}

Satellite images were received by the NERC Dundee Satellite Receiving Station, and processed by Peter Miller at the NERC Remote Sensing Group in Plymouth Marine Laboratories (http:www.npm.ac.ukrsdas). This work was supported by the European Union under the MAST 3 programme, contract number MAS3-CT97-0076 OMEX and Plymouth Marine Laboratory. This work was carried out with the help and enthusiasm of the crew and scientists of the RRS Charles Darwin CD105. 
Akima, H., Rectangular-grid-data surface fitting that has the accuracy of a bicubic polynomial, ACM transactions on Mathematical Software, 22, 357-361, 1996.

Alvarez, I., M. de Castro, M. Gomez-gesteira, and R. Prego, Hydrographic behaviour of the galician rias baixas (nw spain) under the spring intrusion of the miño river, Journal of Marine Systems, In press, 2006.

Álvarez-Salgado, X. A., J. Gago, B. M. Míguez, M. Gilcoto, and F. F. Pérez, Surface water of the NW Iberian margin: upwelling on the shelf versus outwelling of upwelled waters from the Rias Baixas, Estuarine, Coastal and Shelf Science, 51, 821-837, 2000.

Ambar, I., and A. F. G. Fiúza, Some features of the Portugal current system: A poleward slope undercurrent, an upwelling-related summer southward flow and autunm-winter poleward coastal surface current, in Proceedings of the $2^{\text {nd }}$ International Conference on Air-Sea Interaction, Meteorology and Oceanography of the Coastal Zone, edited by K. Katsaros, A. Fiúza, and I. Ambar, p. 311, American Meteorology Society, 1994.

Bakun, A., and C. S. Nelson, The seasonal cycle of wind stress curl in subtropical eastern boundary current regions, Journal of Physical Oceanography, 21, 1815-1834, 1991.

Barnes, S. L., Applications of the Barnes objective analysis sheme, part III: Tuning for minimum error, Journal of Atmospheric and Oceanic Technology, 11, 1459-1470, 1994.

Barth, J. A., S. D. Pierce, and R. L. Smith, A separating coastal upwelling jet at Cape Blanco, Oregon and its connection to the California current system, Deep-Sea Res. Part II-Top. Stud. Oceanogr., 47, 783-810, 2000. 
Brainerd, K. E., and M. C. Gregg, Surface mixed layer and mixing layer depths, Deep-Sea Research I, 42, 1521-1543, 1995.

Carter, E. F., and A. R. Robinson, Analysis models for the estimation of oceanic fields, Journal of Atmospheric and Oceanic Technology, 4, 49-74, 1987.

Castro, C. G., X. A. Alvarez-Salgado, F. G. Figuerias, F. F. Perez, and F. Fraga, Transient hydrographic and chemical conditions affecting microplankton populations in the coastal transition zone of the iberian upwelling system (NW Spain) in September 1986, Journal of Marine Research, 55, 321-352, 1997.

Castro, C. G., F. F. Pérez, X. A. Álvarez-Salgado, and F. Fraga, Coupling between the thermohaline, chemical and biological fields during two constrasting upwelling events off the NW Iberian Peninsula, Continental Shelf Research, 20, 189-210, 2000.

Cummins, P. F., and G. K. Vallis, Algorithm 732: Solvers for self-adjoint elliptic problem in irregular two-dimensional domains, ACM Transactions Mathematical Software, 20, 247-261, 1994.

Doval, M. D., E. Nogueira, and F. F. Pérez, Spatio-temporal variability of the thermohaline and biogeochemical properties and dissolved organic carbon in a coastal embayment affected by upwelling: the Ría de Vigo (NW Spain), Journal of Marine Systems, 14, 135-150, 1998.

Dubert, J., Dynamique du système de courants vers le pôle au voisinage de la pente continentale à l'Ouest et au nord de la péninsule Ibérique, Ph.D. thesis, Université de Bretagne Occidentale, France, 1998.

Firing, E., J. Ranada, and P. Caldwell, Processing ADCP Data with the CODAS Software System Version 3.1, User's Manual, University of Hawaii, 1995. 
Fiúza, A. F. G., Hidrologia e dinamica das aguas costeiras de Portugal, Ph.D. thesis, University of Lisbom, Portugal, 1984.

Frouin, R., A. Fiúza, I. Ambar, and T. J. Boyd, Observations of a poleward surface current off the coasts of Portugal and Spain during the winter, Journal of Geophysical Research, 95, 679-691, 1990.

Hawkins, H. F., and S. L. Rosenthal, On the computation of streamfunctions from the wind field, Monthly Weather Review, 93, 245-252, 1965.

Haynes, R., and E. D. Barton, A poleward flow along the Atlantic coast of the Iberian Peninsula, Journal of Geophysical Research, 95, 11,425-11,141, 1990.

Haynes, R., and E. D. Barton, Lagrangian observations in the Iberian coastal transition zone, Journal of Geophysical Research, 96, 14,731-14,741, 1991.

Haynes, R., E. D. Barton, and I. Pilling, Development, persistence and variability of upwelling filaments off the Atlantic coast of the Iberian peninsula, Journal of Geophysical Research, 98, 22,681-22,692, 1993.

He, R., and R. H. Weisberg, West Florida shelf circulation and temperature budget for the 1999 spring transition, Continental Shelf Research, 22, 719-748, 2002.

Huthnance, J. M., H. M. Van Aken, M. White, E. D. Barton, B. LeCann, E. F. Coelho, E. A. Fanjul, P. Miller, and J. Vitorino, Ocean margin exchangewater flux estimates, Journal of Marine Systems, 32, 107-137, 2002.

Huyer, A., Coastal upwelling in the California current system, Prog. Oceanogr., 12, 259-284, 1983.

Koch, S. E., M. DesJardins, and P. J. Kocin, An interactive Barnes objective map analysis scheme for use with satellite and conventional data, J. Climate Appl. Met., 22, 1487-1503, 1983.

Kosro, P. M., Shipboard acoustic current profiling during the coastal ocean 
dynamics experiment., Ph.D. thesis, UCSD, University of California, La Jolla, Ca., 1985.

Lentz, S., The response of buoyant coastal plumes to upwelling-favorable winds, Journal of Physical Oceanography, 34, 2458-2469, 2004.

Martins, C. S., M. Hamann, and A. F. G. Fiúza, Surface circulation in the eastern North Atlantic, from drifters and altimetry, Journal of Geophysical Research, 107, 10-1-10-22, 2002.

McClain, C. R., S. Chao, L. P. Atkinson, J. O. Blanton, and F. de Castillejo, Wind-driven upwelling in the vecinity of cape finisterre, Spain, Journal of Geophysical Research, 91, 8470-8486, 1986.

Nogueira, E., X. A. Alvárez-Salgado, F. F. Pérez, and G. Casas, Geostrophic wind-stress patterns in the NW Iberian upwelling system. a time series approach, in 3rd EU Conference. Exchange Processes at the Continent/Ocean Margins in the North Atlantic, Vigo, 1997.

Nykjaer, L., and L. Vancamp, Seasonal and interannual variability of coastal upwelling along northwest africa and Portugal from 1981 to 1991, Journal of Geophysical Research, 99, 14,197-14,207, 1994.

Paillet, J., B. LeCann, X. Carton, Y. Morel, and A. Serpette, Dynamics and evolution of a northern MEDDY, Journal of Physical Oceanography, 32, $55-79,2002$.

Peliz, A., T. L. Rosa, A. M. P. Santos, and J. L. Pissarra, Fronts, jets and counter flows in the western Iberian upwelling system, Journal of Marine Systems, 35, 61-77, 2002.

Peliz, A., J. Dubert, A. M. P. Santos, P. B. Oliveira, and B. LeCann, Winter upper ocean circulation in the western iberian basin, fronts, eddies and poleward flows: an overview, Deep-Sea Research I, 52, 621-646, 2005.

Pierce, S. D., R. L. Smith, P. M. Kosro, J. A. Barth, and C. D. Wilson, 
Continuity of the poleward undercurrent along the eastern boundary of the mid-latitude north pacific, Deep-Sea Res. Part II-Top. Stud. Oceanogr., 47 , 811-829, 2000.

Pingree, R. D., Winter warming in the southern bay of biscay and lagrangian eddy kinematics from a deep-drogued argos buoy, Journal of the Marine Biological Association of the U. K., 74, 107-128, 1994.

Pingree, R. D., and B. LeCann, Three anticyclonic slope water oceanic eDDIES (SWODDIES) in the southern bay of biscay in 1990, Deep-Sea Research I, 39, 1147-1175, 1992.

Pollard, R., and J. Read, A method for calibrating ship mounted acoustic doppler profilers and the limitations of gyro compasses, Journal of Atmospheric and Oceanic Technology, 6, 859-865, 1989.

Prego, R., A. W. Dale, M. deCastro, M. Gómez-Gesteira, J. J. Taboada, P. Montero, M. R. Villareal, and V. Pérez-Villar, Hydrography of the pontevedra ria: Intra-annual spatial and temporal variability in a galician coastal system (NW Spain), Journal of Geophysical Research, 106, $19,845-19,857,2001$.

Relvas, P., and E. D. Barton, A separated jet and coastal counterflow during upwelling relaxation off Cape São Vicente (Iberian peninsula), Continental Shelf Research, 25, 29-49, 2005.

Rosenfeld, L. K., F. B. Schwing, N. Garfield, and D. E. Tracy, Bifurcated flow from an upwelling center: A cold water source for Monterey Bay, Continental Shelf Research, 14, 931-964, 1994.

Santos, A. M. P., A. Peliz, J. Dubert, P. B. Oliveira, M. M. Angelico, and P. Re, Impact of a winter upwelling event on the distribution and transport of sardine (Sardina pilchardus) eggs and larvae off western Iberia: a retention 
mechanism, Continental Shelf Research, 24, 149-165, 2004.

Sordo, I., E. D. Barton, J. M. Cotos, and Y. Pazos, An inshore poleward current in the NW of the Iberian peninsula detected from satellite images, and its relation with $g$. catenatum and $d$. acuminata blooms in the Galician Rias, Estuarine, Coastal and Shelf Science, 53, 787-799, 2001.

Sousa, F. M., Processos de Mesoescala ao Largo da Costa Portuguesa Utilizando Dados de Satélite e Observações In Situ, Ph.D. thesis, University of Lisbon, 1995.

Torres, R., and E. D. Barton, Charles darwin CD114 cruise report: Acoustic doppler current fields, Tech. rep., University of Wales, Bangor, 1999.

Torres, R., and E. D. Barton, Onset and development of the iberian poleward flow along the galician coast, Continental Shelf Research, 26,1134-1153, 2006.

Torres, R., E. D. Barton, P. Miller, and E. Fanjul, Spatial patterns of wind and sea surface temperature in the galician upwelling region, Journal of Geophysical Research, 108(C4), 2003.

Wooster, W. S., A. Bakun, and D. R. Mclain, The seasonal upwelling cycle along the eastern boundary of the north Atlantic, Journal of Marine Research, 34, 131-141, 1976. 
1 Location of Coastal weather and CTD stations and Transect names for CD105 cruise. Black diamonds mark the Rías referred to as Rías Baixas. The Ría de Arousa is also labelled. Depth contours of 200, 500, 1000 and $2000 \mathrm{~m}$ are shown.

2 Example of (a) vectorized ADCP data with minimum averaging of $10 \mathrm{~min}$ and $12 \mathrm{~m}$ in the vertical centered at $51 \mathrm{~m}$ and (b) non-divergent ADCP current vectors superimposed on transport streamfunction contours with a $0.01 \times 10^{6} \mathrm{~m}^{3} \mathrm{~s}^{-1}$ contour interval. The line on land indicates the area sampled under upwelling (U) and downwelling (D) conditions.

3 SST weekly averaged images from a) 1-7 June and b) 29 June -05 July 1997 corresponding to leg A and 9 days after the end of cruise CD105. Eddies have been numbered with an E prefix. The 200 and $1000 \mathrm{~m}$ isobath are included. Note the different temperature scale.

4 Daily averaged coastal winds from Corrubedo (C), Finisterre (F) and Vilanova (V). The time of the two cruise legs is indicated in the graph. The sticks point in the direction of the wind with the positive $\mathrm{Y}$ axis aligned to north. Units in $\mathrm{m} \mathrm{s}^{-1}$

5 Underway data collected at the start (10 June 08:45-10:31, grey - thick) and end (20 June 08:13-10:38, black - thin) of leg B of CD105 cruise; (a) temperature (solid line) and salinity (dashed line), (b) top 50m ADCP vector currents with scale on the $\mathrm{y}$ axis and (c) position of observations.

6 Salinity and temperature distribution at $5 \mathrm{~m}$ as recorded by the thermosalinograph from leg A; a) salinity and c) temperature and leg B; b) salinity and d) temperature. In a and $\mathrm{b}$ the isohaline of 35.85 appears as a white dashed line. The structures identified in leg B are indicated as E2 (eddy), $\mathrm{P}$ (poleward flow) and $\mathrm{R}$ (fresh water runoff) and are included in a and $\mathrm{c}$ for reference. A low salinity region found in leg $\mathrm{A}$ is marked as L. Darker shading indicates lower salinity. The line on land separates the areas sampled under upwelling (U) and downwelling (D) conditions. 
7 a) Fluorescence distribution (in Volts) at $5 \mathrm{~m}$ as measured by the CTD from leg B. Darker shading correspond to lower fluorescence values. b) Distribution of surface mixed layer depth using criteria of $\Delta \sigma_{t}=0.1 \mathrm{~kg} \mathrm{~m}^{3}$. The line on land separates the areas sampled under upwelling (U) and downwelling (D) conditions.

8 Near-surface (15m) properties during Leg B 10-20 June 1997.

(a) Salinity; darker shading corresponds to lower salinity.

(b) Fluorescence in Volts; darker shading correspond to higher values. (c) Non-divergent ADCP current vectors with minimum averaging of $10 \mathrm{~min}$ and $12 \mathrm{~m}$ in the vertical centered at $15 \mathrm{~m}$ superimposed on transport streamfunction contours with a $0.01 \times 10^{6} \mathrm{~m}^{3} \mathrm{~s}^{-1}$ contour interval. The line on land separates the areas sampled under upwelling (U) and downwelling (D) conditions.

9 Sub-surface $(50 \mathrm{~m})$ properties during Leg B 10-20 June 1997. (a) Salinity; darker shading corresponds to lower salinity, (b) temperature at $\sigma_{t}=26.4 \mathrm{~kg} \mathrm{~m}^{3}$ isopycnal and (c) non-divergent ADCP current vectors superimposed on transport streamfunction contours with a $0.01 \times 10^{6} \mathrm{~m}^{3} \mathrm{~s}^{-1}$ contour interval. The line on land separates the areas sampled under upwelling (U) and downwelling (D) conditions.

10 Sub-surface (100m) properties during Leg B 10-20 June 1997. (a) Salinity; darker shading corresponds to lower salinity. (b) Temperature; darker shading correspond to warmer temperatures. (c) Non-divergent ADCP current vectors superimposed on transport streamfunction contours with a $0.01 \times 10^{6} \mathrm{~m}^{3} \mathrm{~s}^{-1}$ contour interval. The line on land separates the areas sampled under upwelling (U) and downwelling (D) conditions.

11 Vertical sections (and minimum values) of salinity for transects (a) 1 (35.21 psu), (b) 3 (35.34 psu), (c) 9 (35.34 psu), (d) 7 (34.84 psu), (e) 5 (34.97 psu) and (f) 4 (34.77 psu) down to $300 \mathrm{~m}$. Contouring interval is $0.1 \mathrm{psu}$.

12 Vertical sections of velocity component $\mathrm{V}$ for transects (a) 1, (b) 3, (c) 9, (d) 7, (e) 5 and (f) 4 down to 200m. Shading correspond to northward flow. The 0 velocity contour appears as a dash line. 
13 Vertical sections (and minimum values) of density for transects (a) $1\left(25.36 \mathrm{~kg} \mathrm{~m}^{3}\right)$, (b) $3\left(25.46 \mathrm{~kg} \mathrm{~m}^{3}\right)$, (c) $9\left(25.33 \mathrm{~kg} \mathrm{~m}^{3}\right.$ ), (d) $7\left(24.85 \mathrm{~kg} \mathrm{~m}^{3}\right)$, (e) $5\left(24.78 \mathrm{~kg} \mathrm{~m}^{3}\right)$ and (f) $4(24.54$ $\mathrm{kg} \mathrm{m}^{3}$ ) down to $300 \mathrm{~m}$.

14 Wind stress, $\tau$, Ekman transport, E, geostrophic transport, $G$, alongshore pressure gradient, $\eta_{y}$ and sea level at the coast, $\eta$. Two horizontal coordinate systems $x, y$ and $x^{\prime}, y^{\prime}$ are defined. Coastal points $\mathrm{A}$ and $\mathrm{B}$, and segments 1, 2 and 3 are labelled. The $200 \mathrm{~m}$ isobath is also shown. 


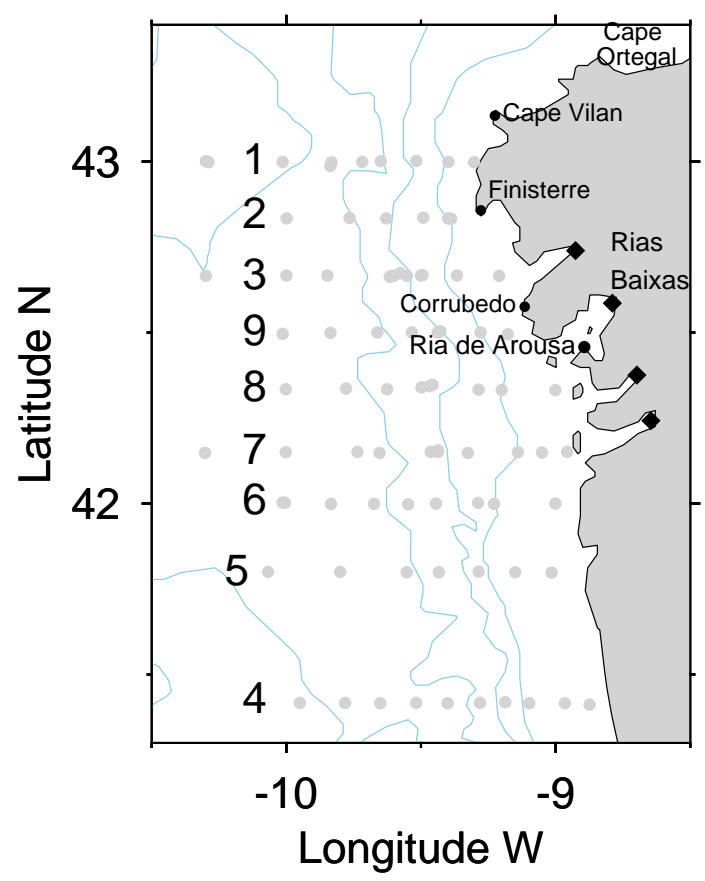

Fig. 1. Location of Coastal weather and CTD stations and Transect names for CD105 cruise. Black diamonds mark the Rías referred to as Rías Baixas. The Ría de Arousa is also labelled. Depth contours of 200, 500, 1000 and $2000 \mathrm{~m}$ are shown. 
(a)

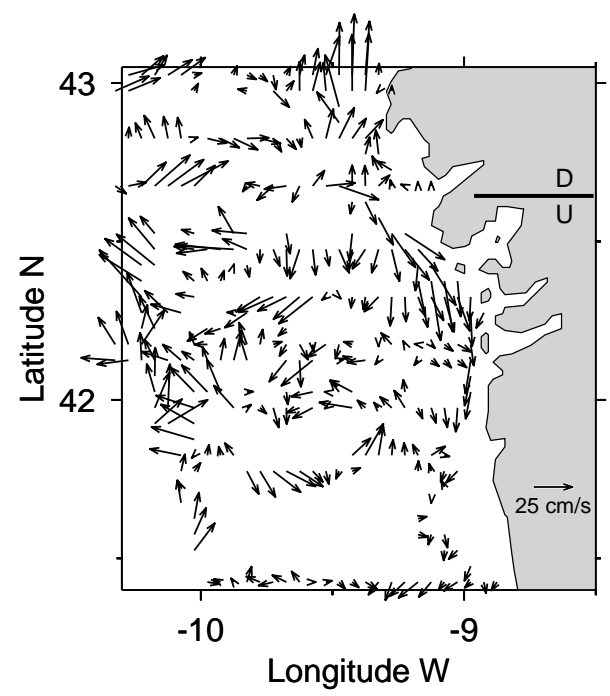

(b)

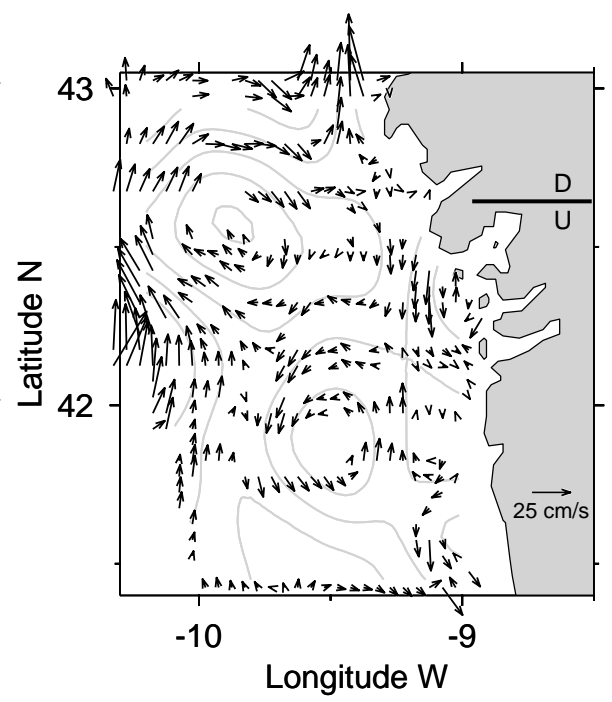

Fig. 2. Example of (a) vectorized ADCP data with minimum averaging of $10 \mathrm{~min}$ and $12 \mathrm{~m}$ in the vertical centered at $51 \mathrm{~m}$ and (b) non-divergent ADCP current vectors superimposed on transport streamfunction contours with a $0.01 \times 10^{6} \mathrm{~m}^{3} \mathrm{~s}^{-1}$ contour interval. The line on land indicates the area sampled under upwelling (U) and downwelling (D) conditions. 
(a)

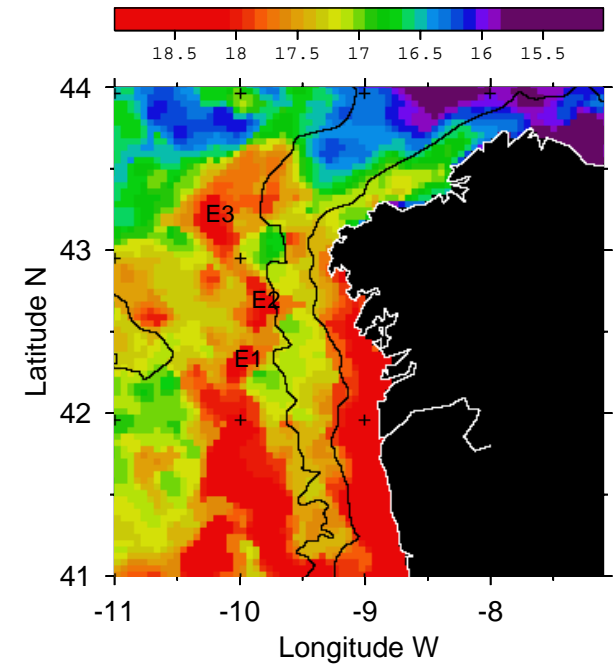

(b)

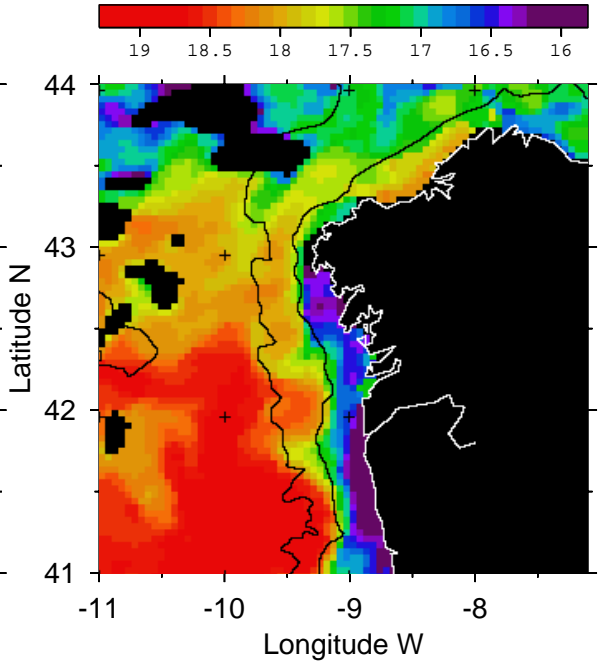

Fig. 3. SST weekly averaged images from a) 1-7 June and b) 29 June -05 July 1997 corresponding to leg A and 9 days after the end of cruise CD105. Eddies have been numbered with an E prefix. The 200 and $1000 \mathrm{~m}$ isobath are included. Note the different temperature scale. 

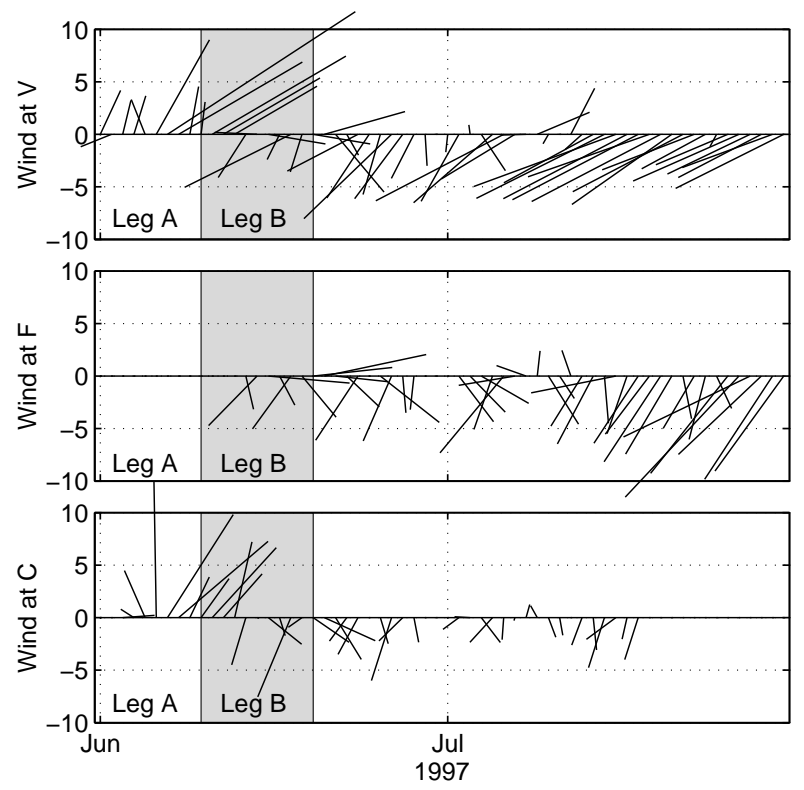

Fig. 4. Daily averaged coastal winds from Corrubedo (C), Finisterre (F) and Vilanova $(\mathrm{V})$. The time of the two cruise legs is indicated in the graph. The sticks point in the direction of the wind with the positive $\mathrm{Y}$ axis aligned to north. Units in $\mathrm{m} \mathrm{s}^{-1}$ 

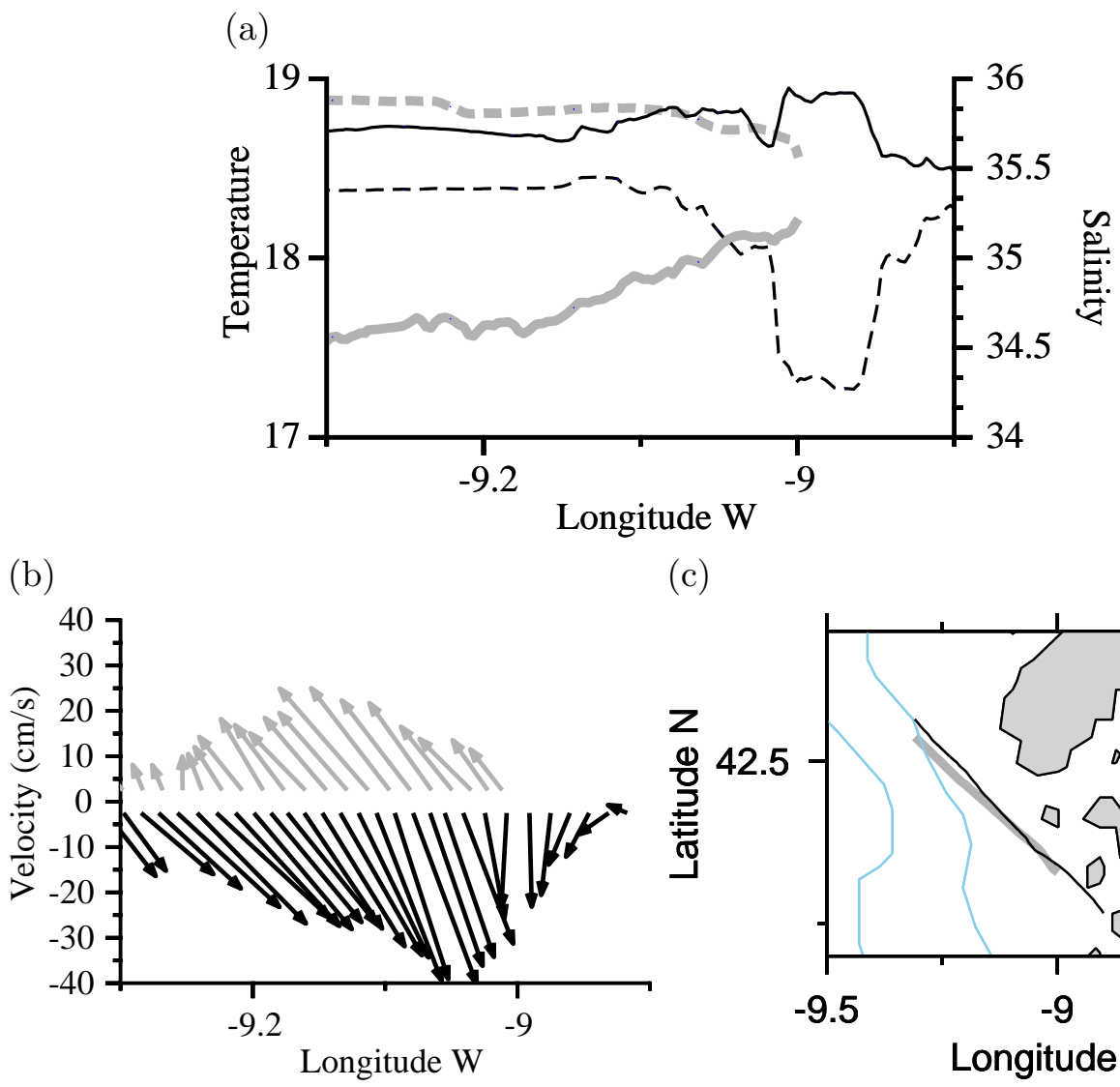

(c)

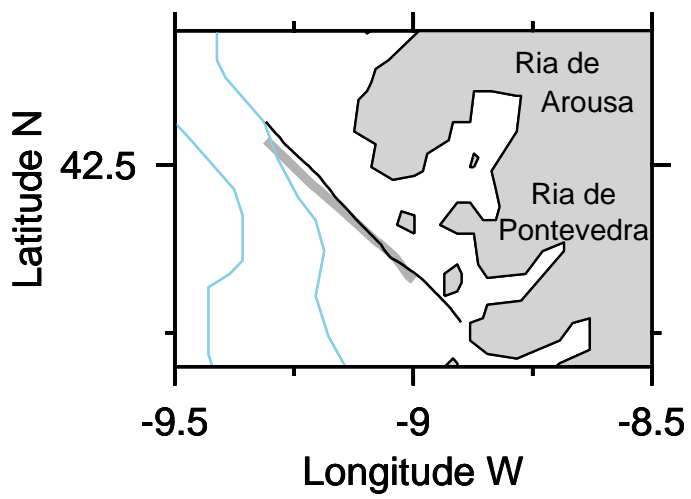

Fig. 5. Underway data collected at the start (10 June 08:45-10:31, grey - thick) and end (20 June 08:13-10:38, black - thin) of leg B of CD105 cruise; (a) temperature (solid line) and salinity (dashed line), (b) top 50m ADCP vector currents with scale on the $y$ axis and (c) position of observations. 
(a)

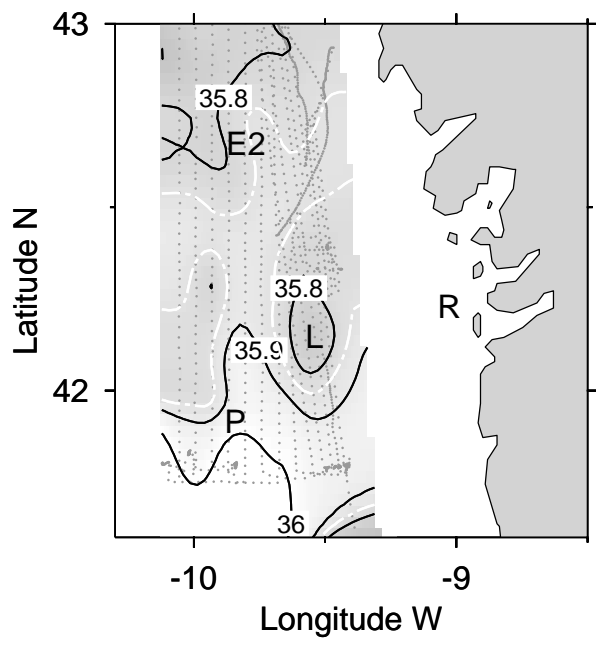

(c)

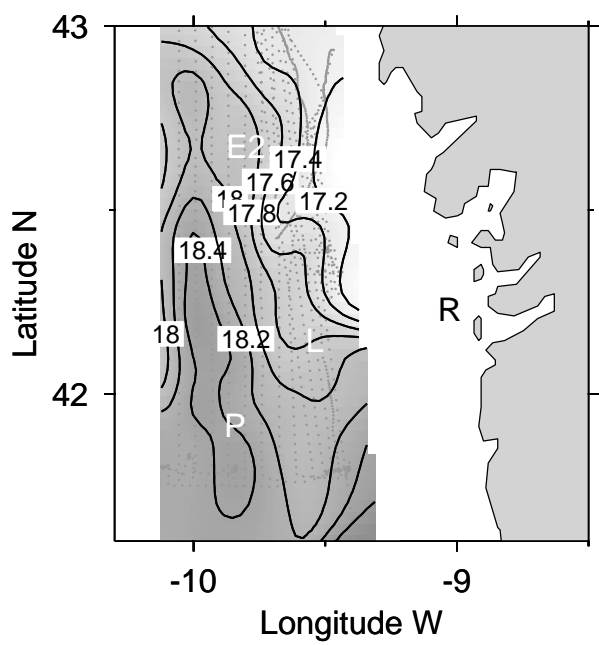

(b)

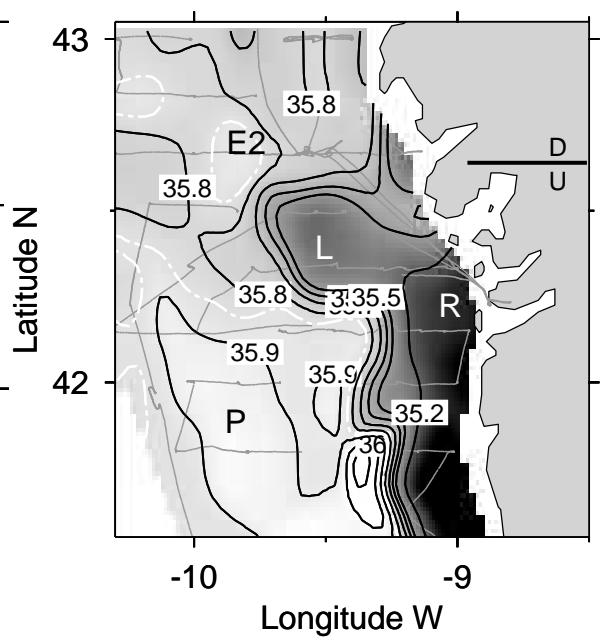

(d)

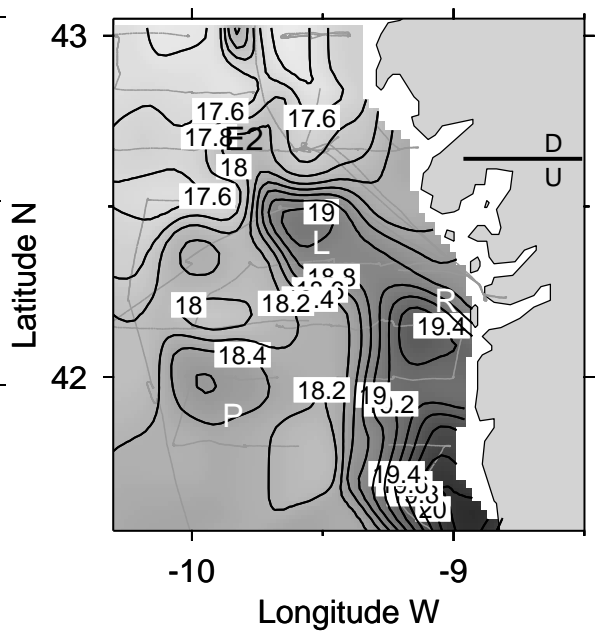

Fig. 6. Salinity and temperature distribution at $5 \mathrm{~m}$ as recorded by the thermosalinograph from leg A; a) salinity and c) temperature and leg B; b) salinity and d) temperature. In a and $\mathrm{b}$ the isohaline of 35.85 appears as a white dashed line. The structures identified in leg B are indicated as E2 (eddy), P(poleward flow) and $\mathrm{R}$ (fresh water runoff) and are included in a and $\mathrm{c}$ for reference. A low salinity region found in leg A is marked as L. Darker shading indicates lower salinity. The line on land separates the areas sampled under upwelling (U) and downwelling (D) conditions. 
(a)

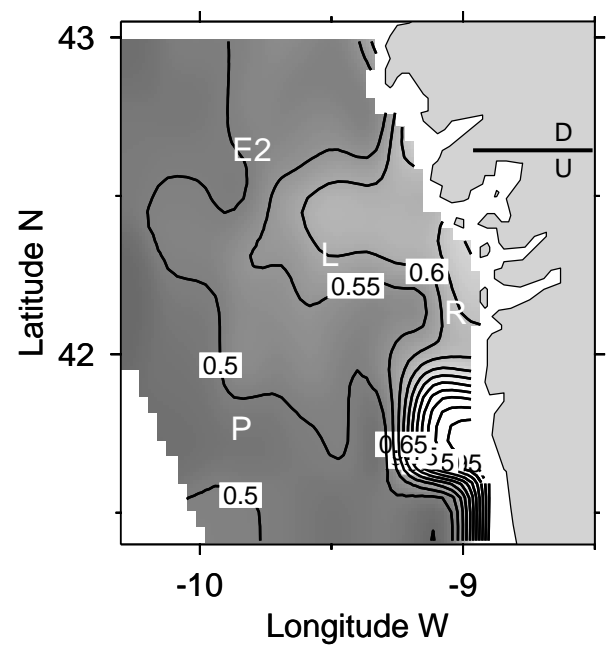

(b)

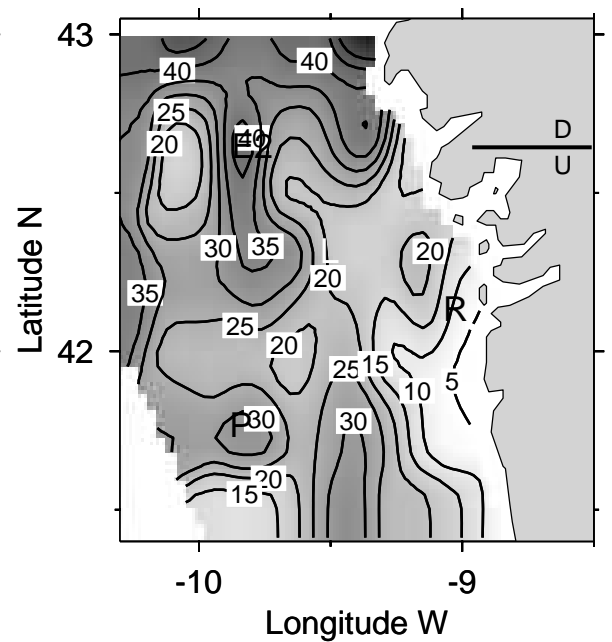

Fig. 7. a) Fluorescence distribution (in Volts) at $5 \mathrm{~m}$ as measured by the CTD from leg B. Darker shading correspond to lower fluorescence values. b) Distribution of surface mixed layer depth using criteria of $\Delta \sigma_{t}=0.1 \mathrm{~kg} \mathrm{~m}^{3}$. The line on land separates the areas sampled under upwelling (U) and downwelling (D) conditions. 
(a)

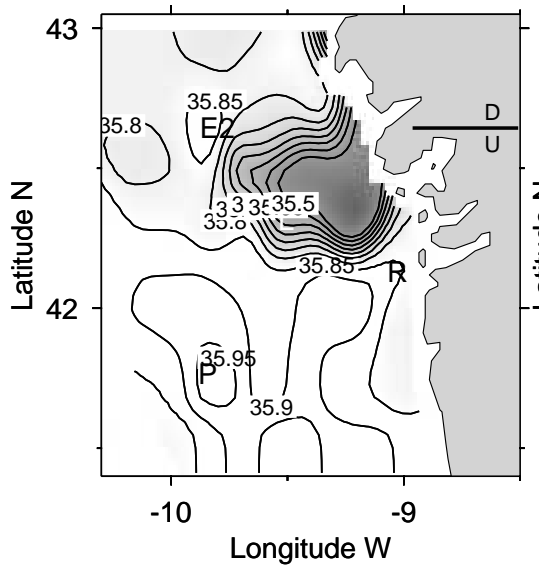

(c) (b)

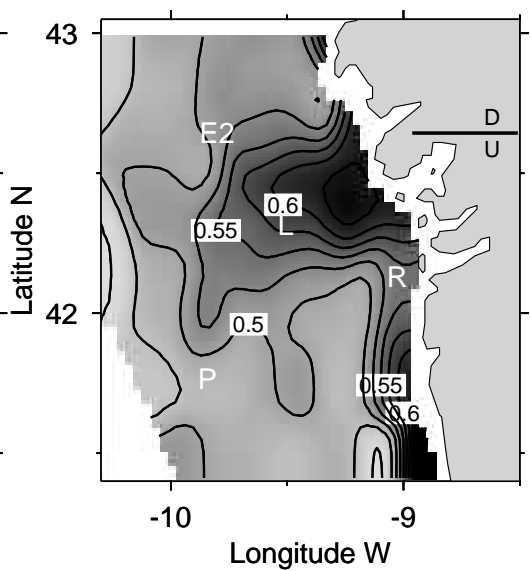

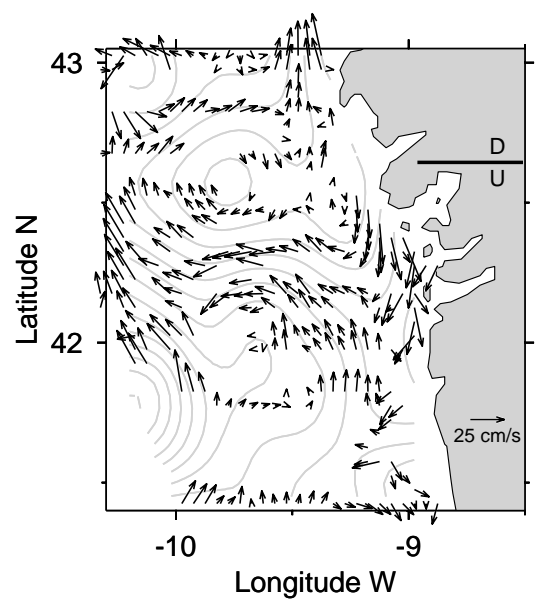

Fig. 8. Near-surface (15m) properties during Leg B 10-20 June 1997. (a) Salinity; darker shading corresponds to lower salinity. (b) Fluorescence in Volts; darker shading correspond to higher values. (c) Non-divergent ADCP current vectors with minimum averaging of $10 \mathrm{~min}$ and $12 \mathrm{~m}$ in the vertical centered at $15 \mathrm{~m}$ superimposed on transport streamfunction contours with a $0.01 \times 10^{6} \mathrm{~m}^{3} \mathrm{~s}^{-1}$ contour interval. The line on land separates the areas sampled under upwelling (U) and downwelling (D) conditions. 
(a)

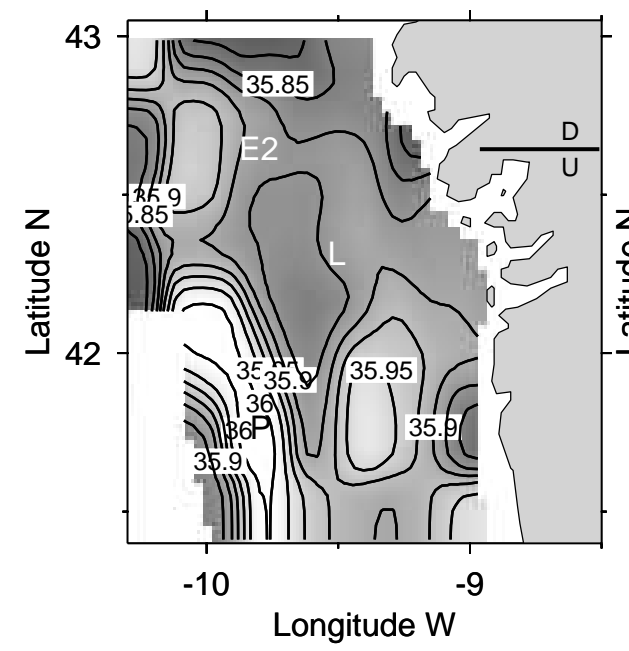

(c) (b)

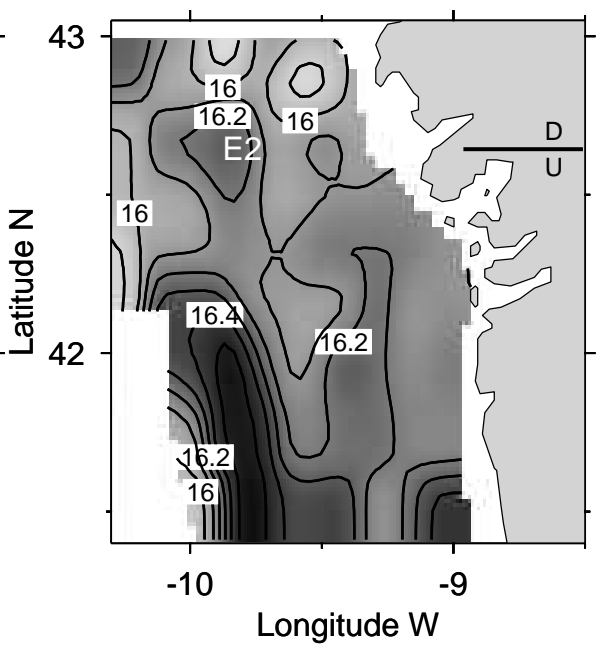

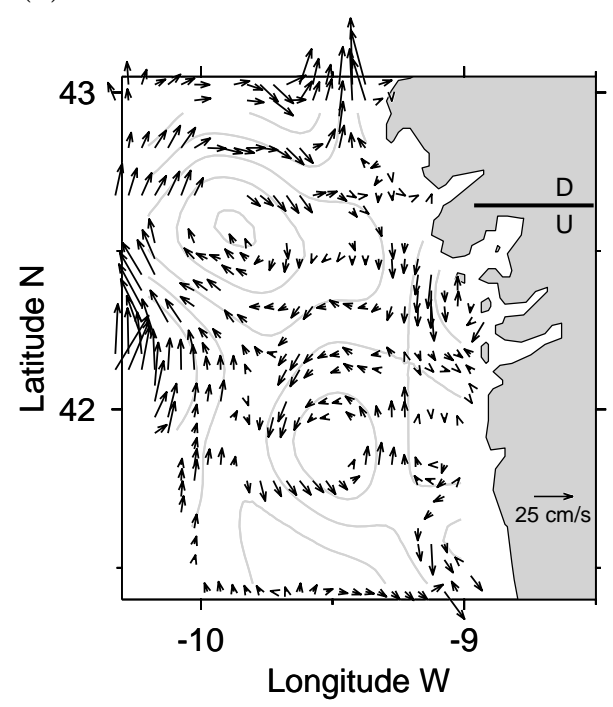

Fig. 9. Sub-surface (50m) properties during Leg B 10-20 June 1997. (a) Salinity; darker shading corresponds to lower salinity, (b) temperature at $\sigma_{t}=26.4 \mathrm{~kg} \mathrm{~m}^{3}$ isopycnal and (c) non-divergent ADCP current vectors superimposed on transport streamfunction contours with a $0.01 \times 10^{6} \mathrm{~m}^{3} \mathrm{~s}^{-1}$ contour interval. The line on land separates the areas sampled under upwelling (U) and downwelling (D) conditions. 
(a)

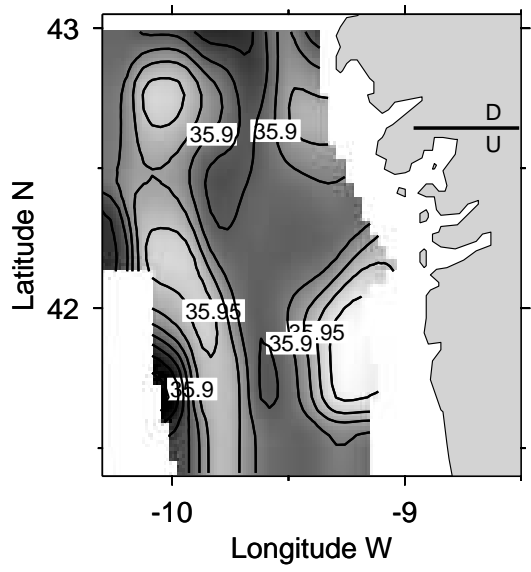

(c)

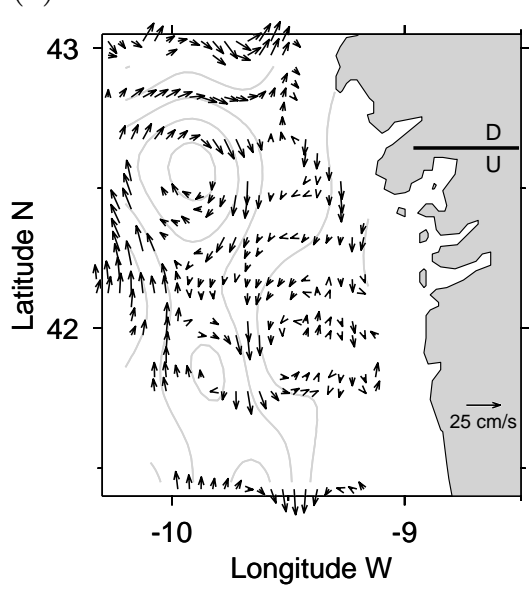

Fig. 10. Sub-surface (100m) properties during Leg B 10-20 June 1997. (a) Salinity; darker shading corresponds to lower salinity. (b) Temperature; darker shading correspond to warmer temperatures. (c) Non-divergent ADCP current vectors superimposed on transport streamfunction contours with a $0.01 \times 10^{6} \mathrm{~m}^{3} \mathrm{~s}^{-1}$ contour interval. The line on land separates the areas sampled under upwelling (U) and downwelling (D) conditions. 
(a)

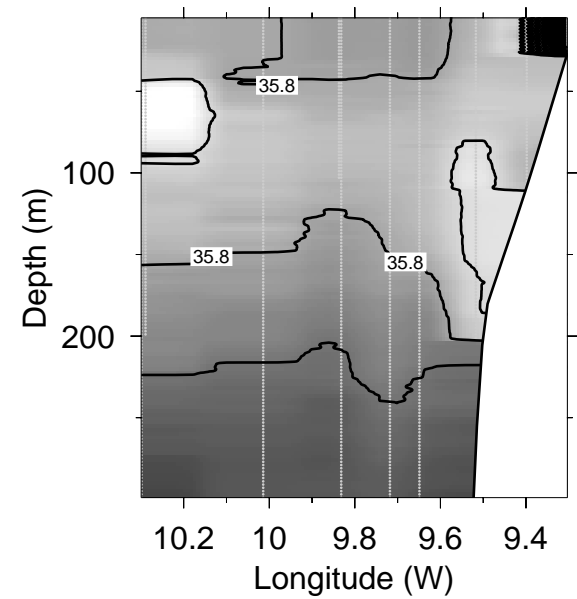

(c)

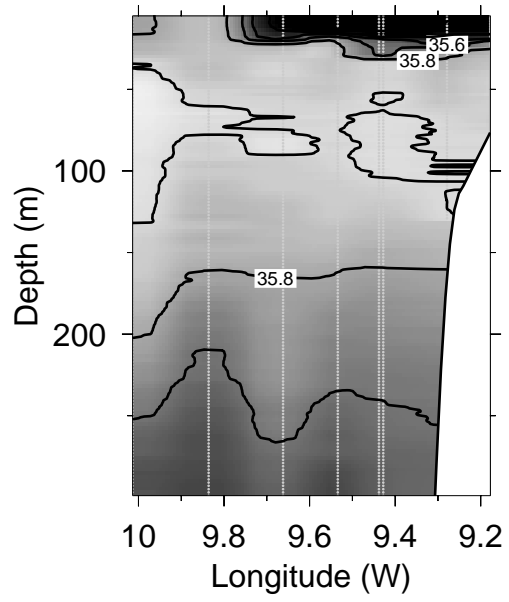

(e)

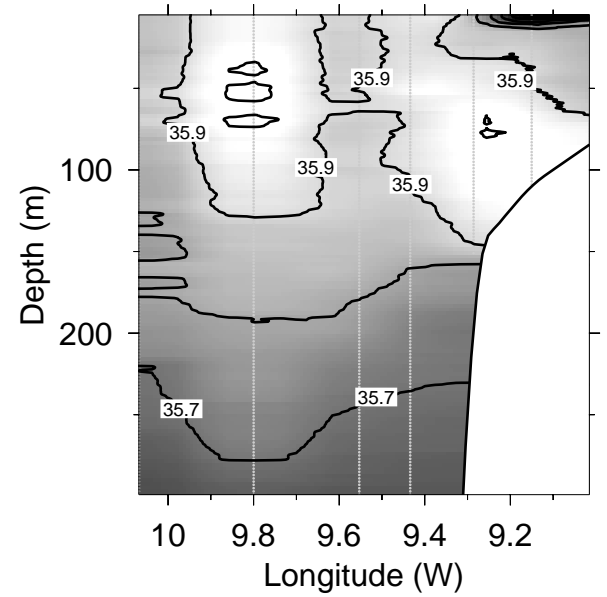

(d) (b)
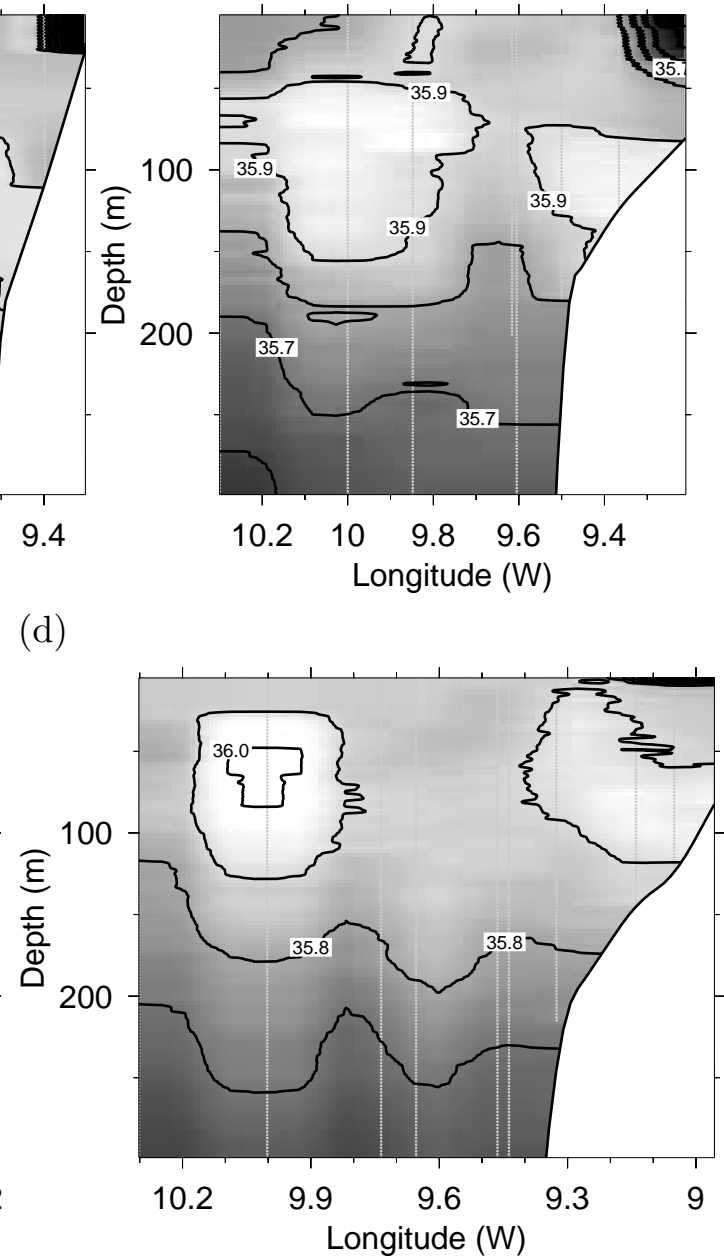

(f)

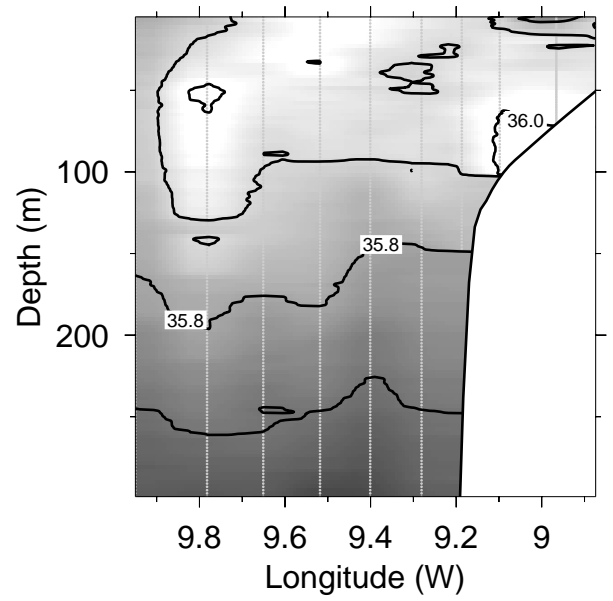

Fig. 11. Vertical sections (and minimum values) of salinity for transects (a) 1 (35.21 psu), (b) 3 (35.34 psu), (c) 9 (35.34 psu), (d) 7 (34.84 psu), (e) 5 (34.97 psu) and (f) $4(34.77 \mathrm{psu})$ down to $300 \mathrm{~m}$. Contouring interval is $0.1 \mathrm{psu}$. 
(a)

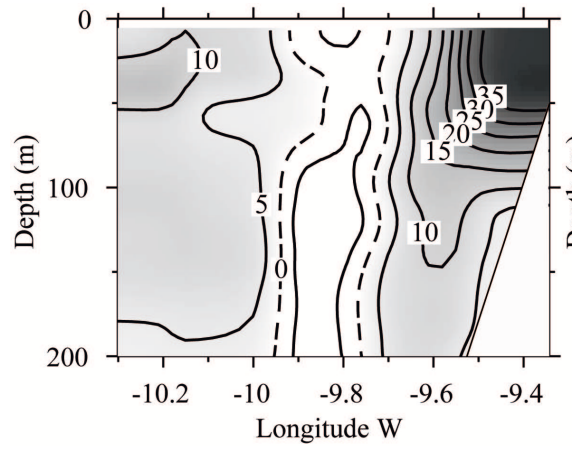

(b)

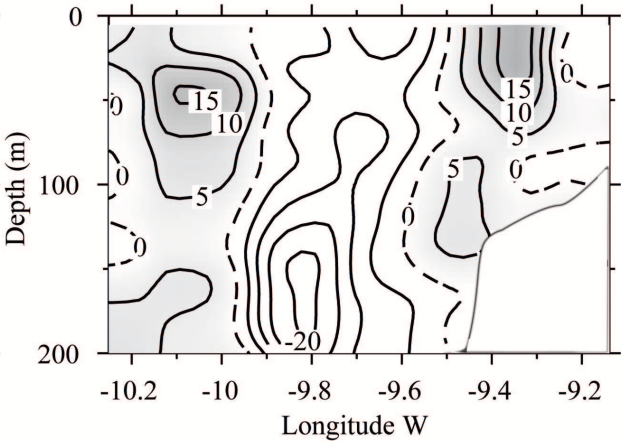

(c)

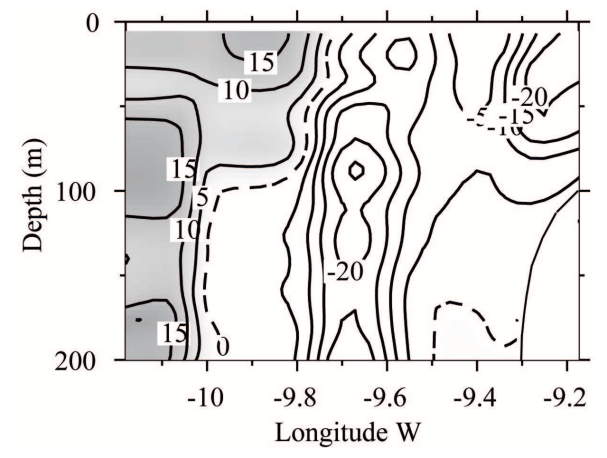

(e)

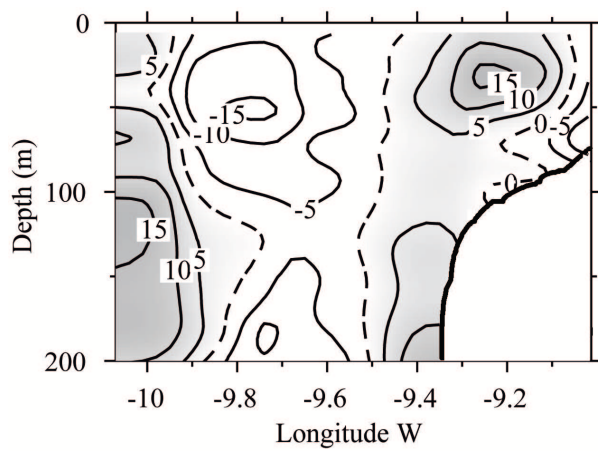

(d)

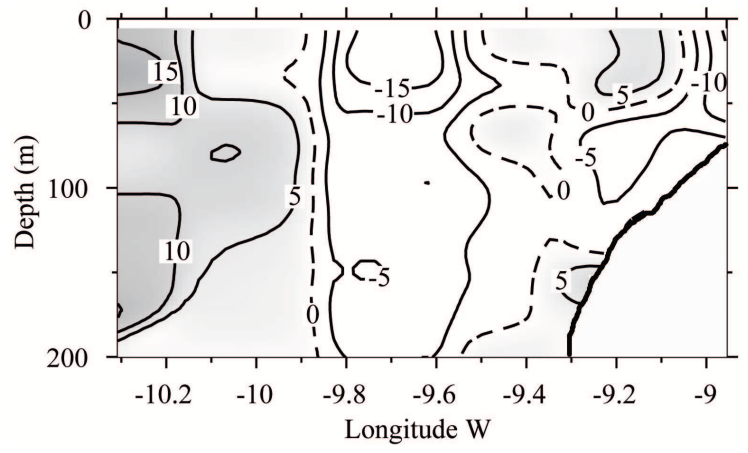

(f)

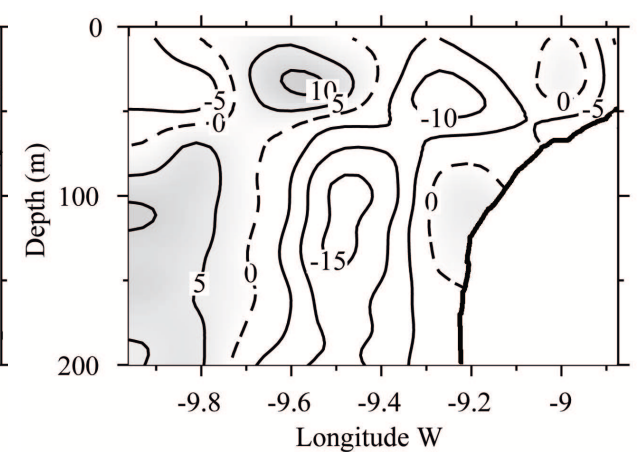

Fig. 12. Vertical sections of velocity component $\mathrm{V}$ for transects (a) 1, (b) 3, (c) 9, (d) 7 , (e) 5 and (f) 4 down to $200 \mathrm{~m}$. Shading correspond to northward flow. The 0 velocity contour appears as a dash line. 
(a)

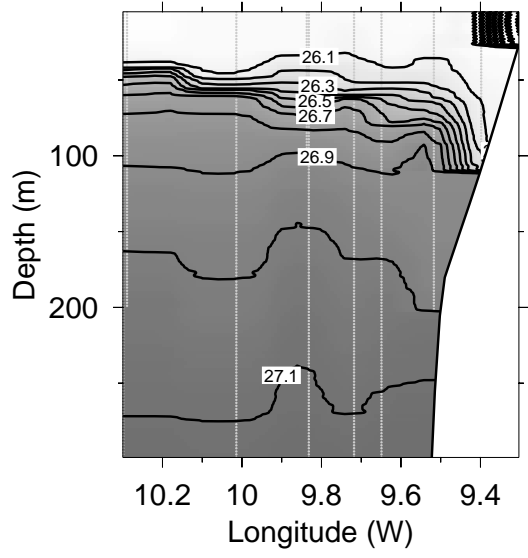

(b)

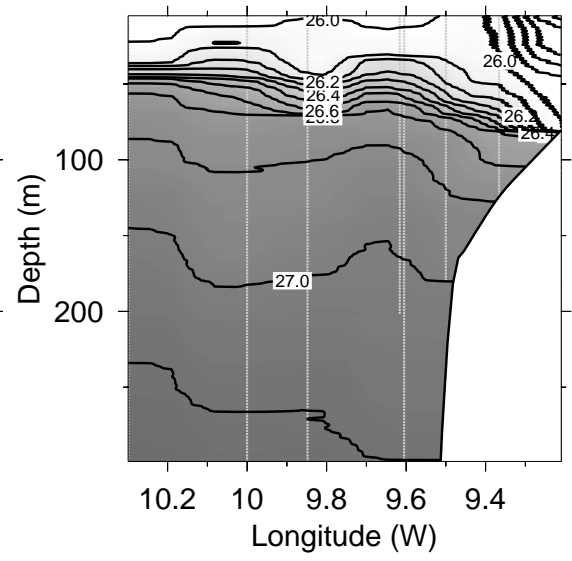

(c)

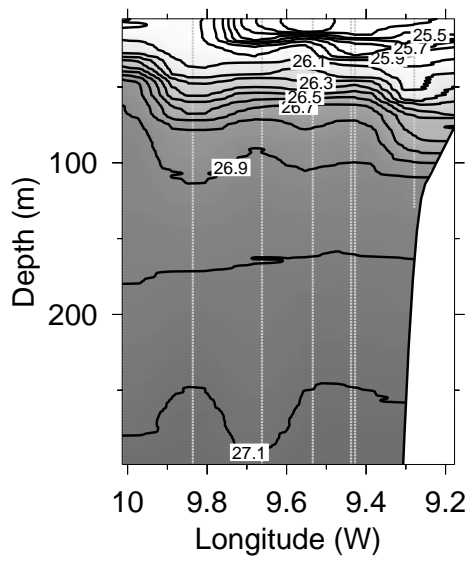

(e)

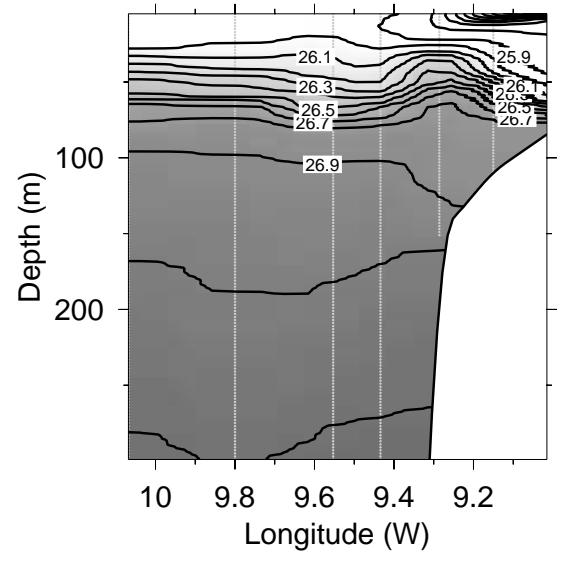

(d)

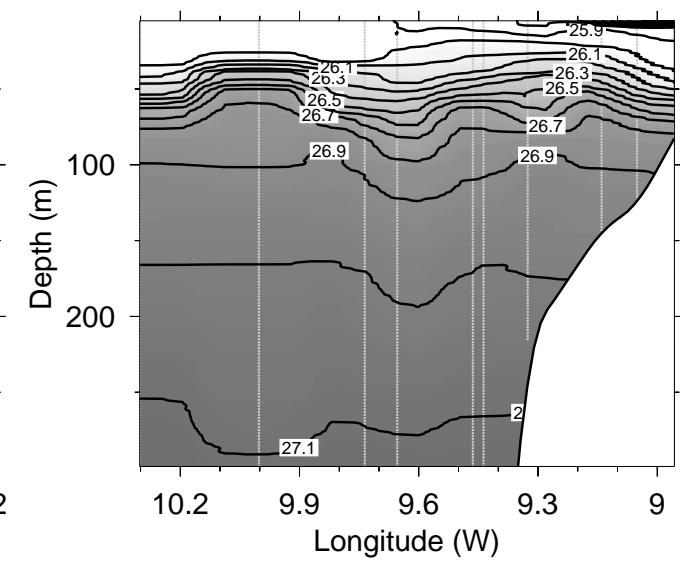

(f)

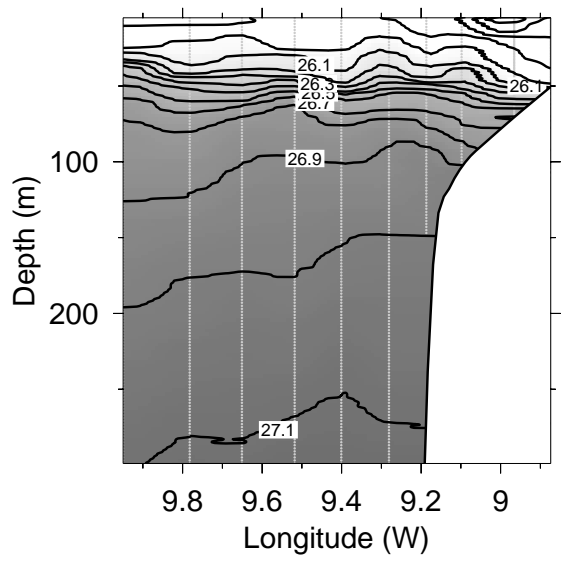

Fig. 13. Vertical sections (and minimum values) of density for transects (a) 1 (25.36 $\mathrm{kg} \mathrm{m}^{3}$ ), (b) $3\left(25.46 \mathrm{~kg} \mathrm{~m}^{3}\right)$, (c) $9\left(25.33 \mathrm{~kg} \mathrm{~m}^{3}\right)$, (d) $7\left(24.85 \mathrm{~kg} \mathrm{~m}^{3}\right.$ ), (e) 5 $\left(24.78 \mathrm{~kg} \mathrm{~m}^{3}\right)$ and (f) $4\left(24.54 \mathrm{~kg} \mathrm{~m}^{3}\right)$ down to $300 \mathrm{~m}$. 


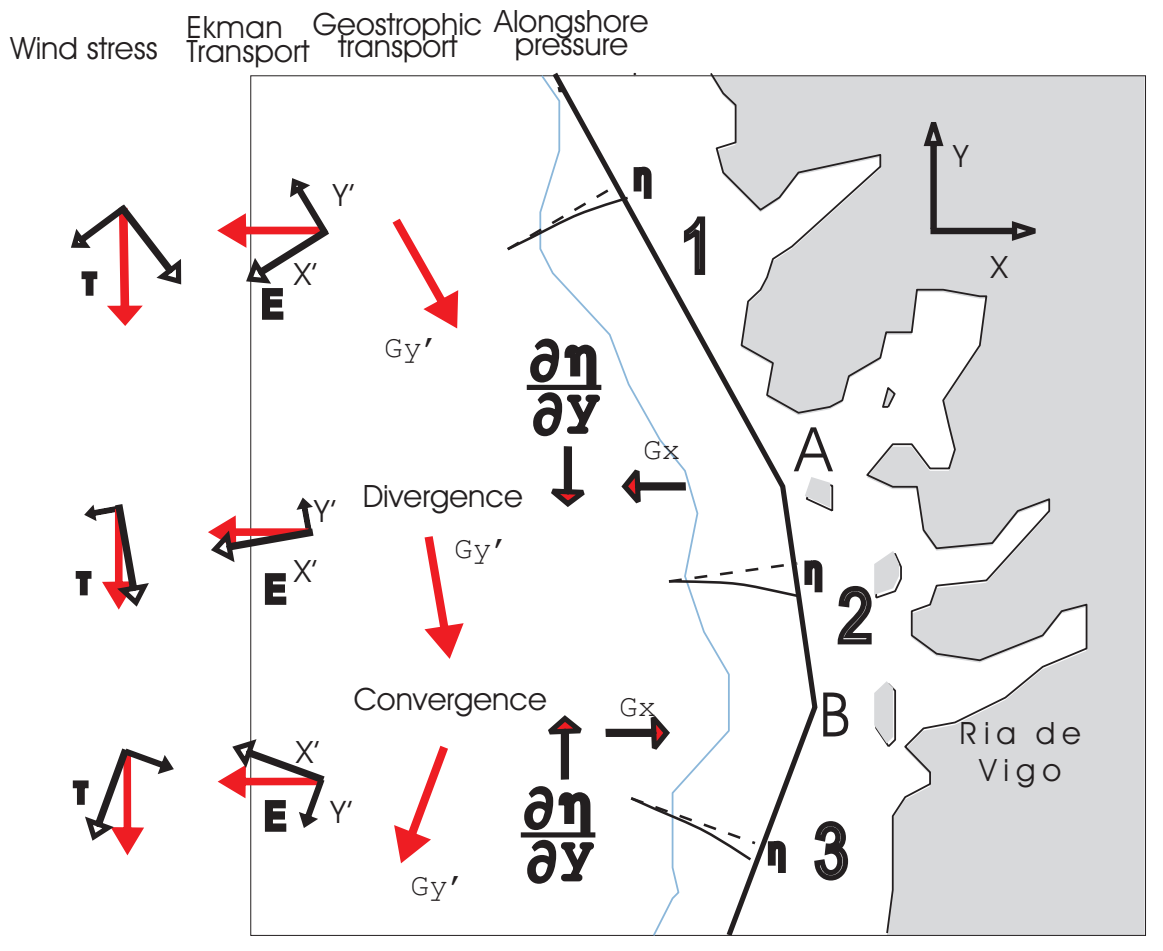

Fig. 14. Wind stress, $\tau$, Ekman transport, $E$, geostrophic transport, $G$, alongshore pressure gradient, $\eta_{y}$ and sea level at the coast, $\eta$. Two horizontal coordinate systems $x, y$ and $x^{\prime}, y^{\prime}$ are defined. Coastal points $\mathrm{A}$ and $\mathrm{B}$, and segments 1, 2 and 3 are labelled. The $200 \mathrm{~m}$ isobath is also shown. 